\title{
تصميم بيئة تعلم تكيفية لعلاج صعوبات تعلم القواعد النحوية لدى طلاب المرحلة الإعدادية
}

\section{أحمدابراهيم عبر السلام أحمد عرايي}

\section{مقدمسة البحـث :}

خلال التقنية مستغلاً في ذلك كل إمكانياتــه.

المتاحة. (*)

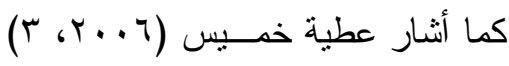

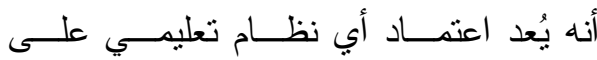

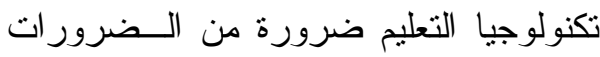

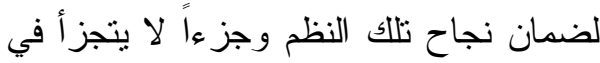
بنية منظومتها، ويحاول الكثير من التربويون الاستفادة مما تقدمه التكنولوجيا من إمكانيات عريضة ومتعددة بهــف تطــــير عمليتـي التعليم و التعلم ورفع كفاءة الأداء.

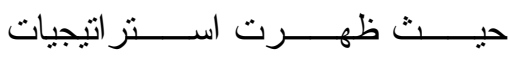

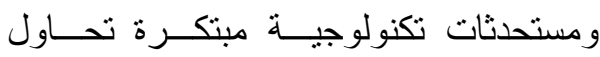
التصدي للمشكلات التعليمية بهــدف إيجــاد حلول غير تقليدية لها وتقديم المساعدة الفعالة للمعلم للقيام بمهامه بصورة أكثتـر كفــــاءة،

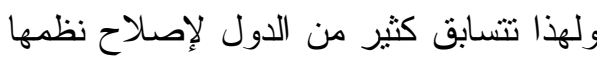

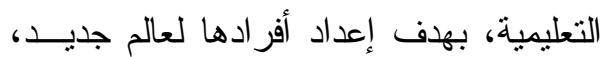

* يتبع الباحث في التوثيق وكتابة المر اجع نظــام

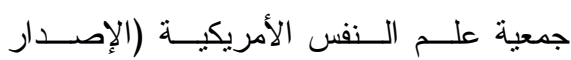
American Psychological (الـسادس) .Association - APA - 6 Edition
يشهـ العصر الحالي تغير ات جذريــة في جميع مناحي الحياة بصفة عامسـة، وفــي التعليم بصفة خاصة، حيث ظهرت العديد من التقنيات التي أصبح من الو اجب علينا محاولة توظيفها و استغلالها لخدمة العملية التعليمية.

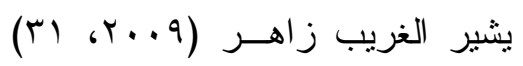

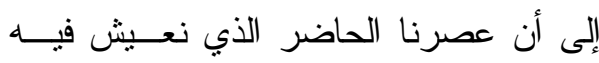

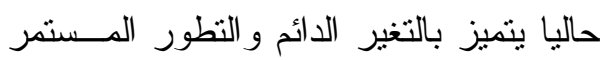

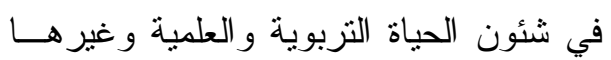

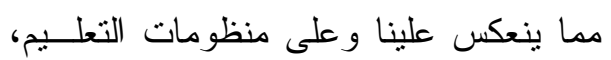

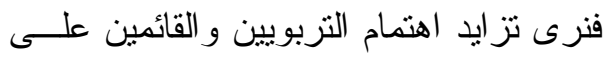
التعليم في العصر الحالي بالمتغير ات الحديثة في تقنية الحاسوب و الوسائل المعينة على نقل بعل وتداول المعرفة ، فقاعلية هذه التقنية أصــبح

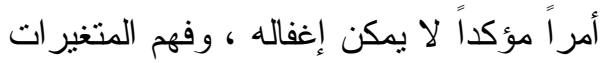

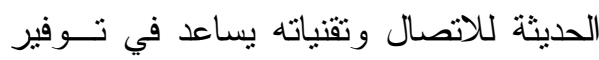

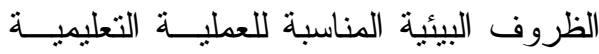

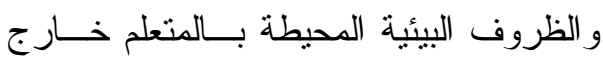

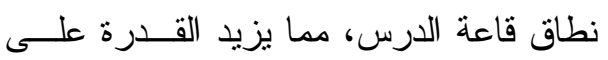
رفع معدل التحصيل بعيداً عن الإلقاء وسرد فئد المعلومات، فيتحول دور الطالب من مستقبل للمعلومات إلى متفاعل مع البيئة التعليمية من لن دورن 
ويهدف إلى تمكين المتعلمـين الأفــر اد فــي

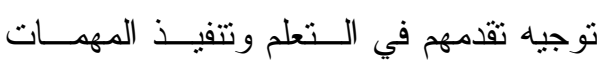

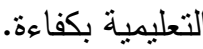

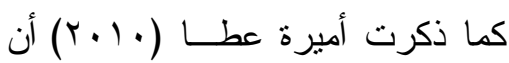

التكيف هو أن تكون علـى در ايــة بـسلوك

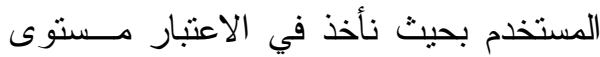

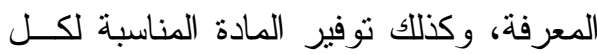

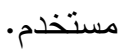

Andreas, ) برى أندرس وســيمون

(Symeon, 2002

التطبيقات التعليمية، حيث بـستخدمها فئـات

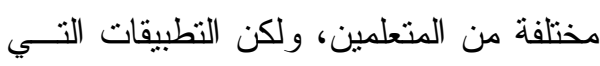

تقدمها أنظمة التعلم القائم عبر الويب التقليدية

تعاني من بعض المشكلات ومنها عدم وجود

اهتمام بالصفحات الشخصية للمتعلمين مسن بـن

حيث معرفتهم السابقة عن الموضوع الــذي بـني يدرسونه أو أسلوب التعلم.

وكما ذكر بورجس وكوبر وتانيرسال

(Tattersall, Koper, Burgos, 2006) أنه يوجد ثلاثة أنماط مختلفة للتكيــف فــي , للني التعلم الإلكتروني: التكيف القائم على واجهة التفاعل ويشمل شكل الواجهة من حيث حجم الخطوط ولونها كتلميح بــصري، الخلفيــة وتوزيع عناصر ها بشكل منوازن مع طبيعة بـونة المحتوى التعليمي، و أسلوب تنعلم الطـــلاب. و التكيف القائم على التعلم التفاعلي حيث تـــتم

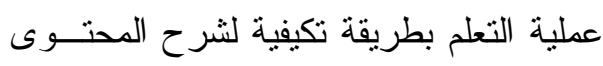

ولمو اجهة التحديات و التحو لات التى يشهدها العصر الحالى، فلابد من التحرر من تقليدية

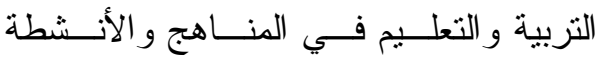
التعليمية، و الذي أصبح اليوم أمر اً ضرورياً. فلم يعد الهذف يقتصر على إكسـساب المتعلم المعارف و الحقائق فقط، بل تعداه إلى لـ لـ

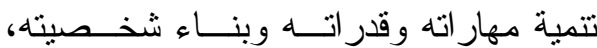

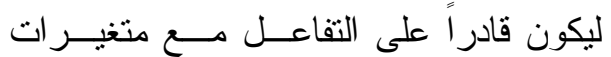
العصر ويستطيع التكيف فى المجتمع الـــى يعيش فيه، فنحن نرى اتجاه أســاليب الــتعلم

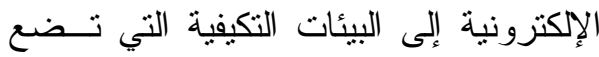
المتعلم في تفاعل مع المحتوى التعليمي، ولقد وضح عطية خميس (10 ب T، \&) بأن بيئسة التعلم التكيفية الذكية تتكــون مــن واجهــة التفاعل التي يتفاعل المتعلمون من خلالهــا، وهي قابلة للتعديل و التحديث في أي وقــت، كما أنها تسمح للنظام بنتبع المتعلم وتــسجيل الأنشطة التي يقوم بها بشكل دوري، وفـي ضوء ذلك تقوم آلية البناء التكيفي باختيــار

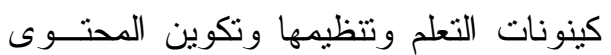
المولد، ثم إرساله إليه. - اليه

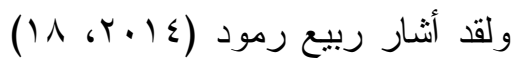
إلى أن محتوى البيئة التكيفية يهدف إلى تقديم

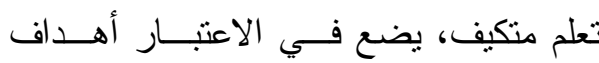

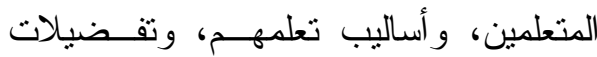
العرض، ومنطلبات الأداء، كما يهدف إلـى ولى ولي

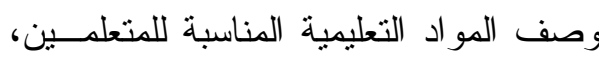


يتم بها التعبير كتابياً عن الأفكار، كما أنهـا

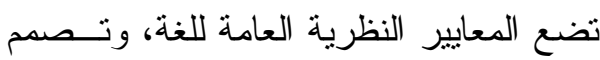
تلالك المعايير التي يتم بها سلامة الكتابة مــن الأخطاء النحوية، كما أنها السبيل الذي يحفظ لهائل

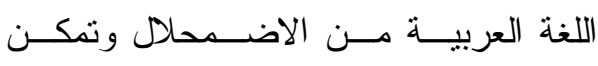

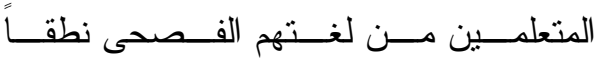

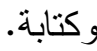

وذكر نجم الموســوي (q...4، (q)

بعض أسباب الصعوبات التي يعـاني منهـــا التلاميذ في القو اعد النحوية، وهي كالتــالي: حفظ القو اعد النحوية بالتلقين، حفظ القو اعـــ من قبل التلاميذ دون فهمها، عـدم مناســبة الكتاب لأعمار التلاميذ، ضعف الطلاب فـي القر اعة و الكتابة، ضعف الاهتمــام بالأمثلــــة الو اقعية (الحسية) للموضوعات النحوية، عدم

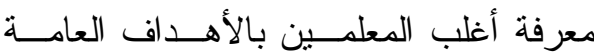

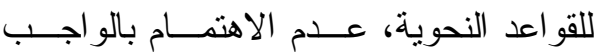
البيتي. الإحسساس بمشكلة البحث :

لقد نبع إحساس الباحث بمشكلة البحث

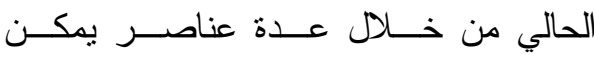
توضيحها فيما يلي:

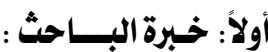

لاحظ الباحث من خلال عمله كمعلـم

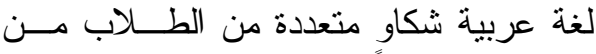
صعوبة فهم القو اعد النحوية، وأيضاً شكاوي منيك متعددة من معلمي اللغة العربية في صــعوبة
التعليمي بطرق مختلفة. التكيف القائم علـى

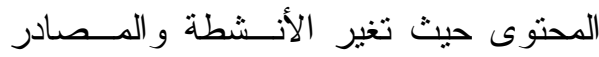

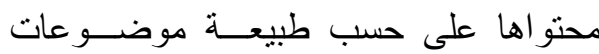
المحتوى و الأسلوب التعليمي للطلاب.

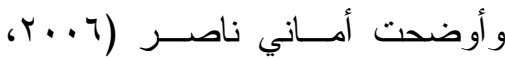
ب أن التكيف نتيجة تفاعل الطالــب مـــع المو اقف التربوية، وهو محصلة لتفاعل عدد من العوامل، منها: ميوله، نــضـج أهدافــه، اتجاهاته نحو النظام المدرسي، اتجاهاته نحو المو اد الدر اسية، علاقته برفقائسـهـه ومعلميــه، مستوى طموحه.

ومن التطور ات التي شــــهـا مجـــال

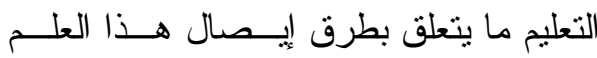

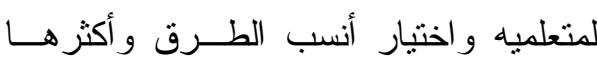

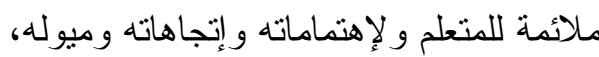
وبذلك يتحقق المطلوب وهو وصول المعلومة بشكلها الصحيح للمتعلم. ولا شك أن القو اعد النحويــة تحتــلـ مكانة هامة من بين فروع اللغة العربية، فهي

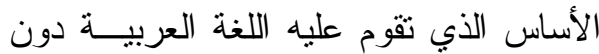

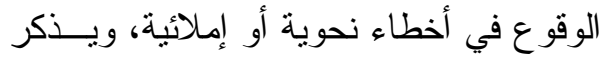

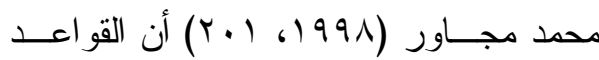
النحوية عملية تقنين للقو اعد و التعميمات التي تصف نزكيب الجمل و الكلمات و عملها فـي

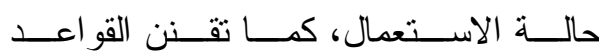

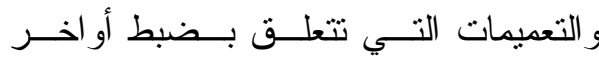
الكلمات، وهي موجه وفائد إلى الطرق التي لنيات 


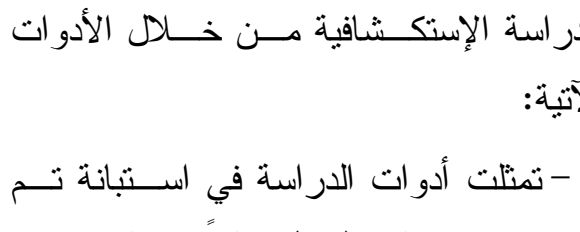

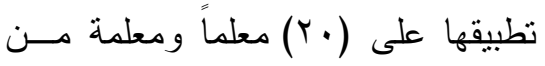

خلد إحدى المدارس الحكومية حــول

مدى تمكن الطلاب من القواعد النحوية

التي تمت در استها، وهل يوجد مشكلات

في دراسة بعض القو اعد النحوية؟، وهل وهل دلون

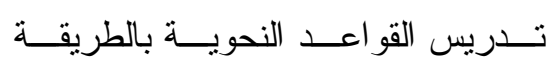

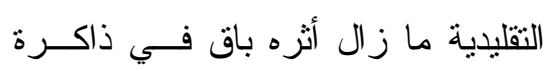

التلاميذ.

- إجر اء مقابلة شخصية مــع (ro) مـن

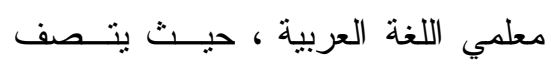

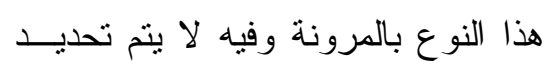

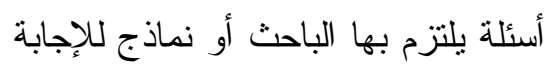

عليها، ويعد هذا النــوع مـن المقابلـــة

كما يرى خير الدين عــويس (1997)

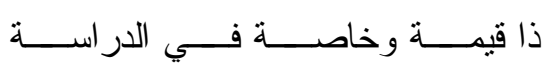

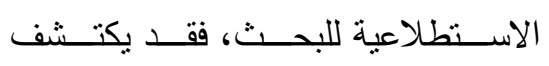

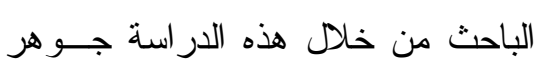

المشكلة.

وقد أسفرت نتــائج الار اســات الاستكثافية و المقابلة غير المقتنة عن الآتي :

• أن 9 \% من مجموع أفراد العينة لديهخ

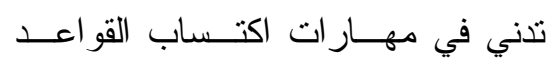

النحوية وفهمها وتذكر ها.
تدريس منهج القو اعــــ النحويـــة و إيــصال

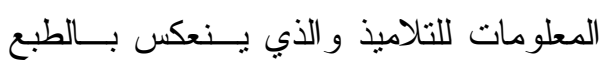
على مستوى التلاميذ. مما سبق يتضح وجود صعوبات فـي

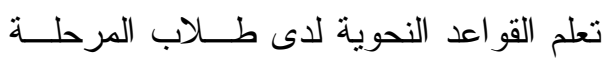

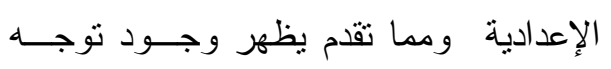

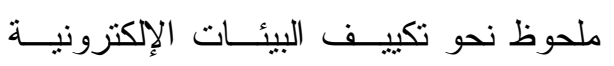
للتغلب على صعوبات الــتعلم فـي التعلــيم

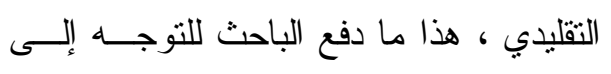

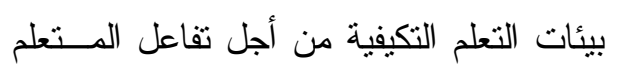

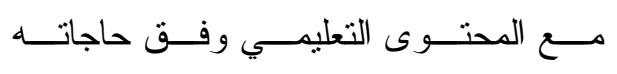

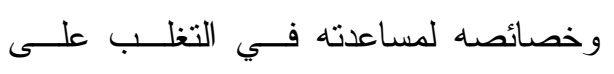
صعوبات تعلمه . وخصنئه لمساعله

ولذلك يسعى الباحث من خلال هــــ

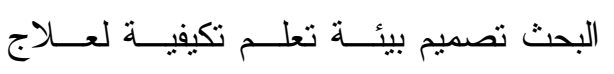

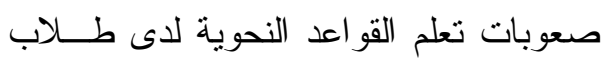
المرحلة الإعدادية . ثانياً: الار اســـة الإستكشافـية :

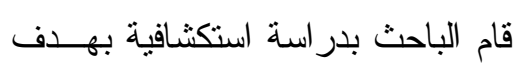
تحديد الصعوبات في تعلم القواعد النحويــة

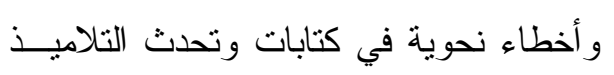
بالمرحلة الإعدادية في عدد من موضوعات فئات ونات

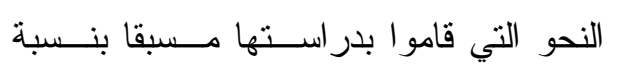

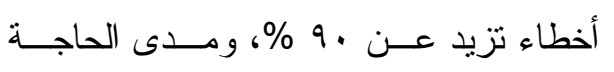

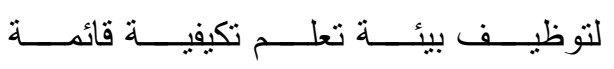

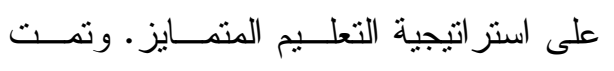




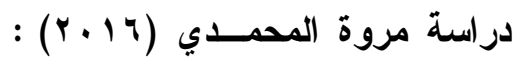

و التي هدفت إلى تصميم بيئة تعلم إلكترونيــة دونة

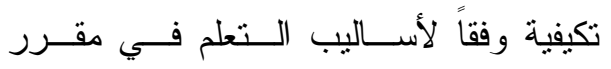

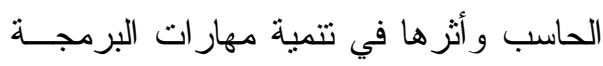

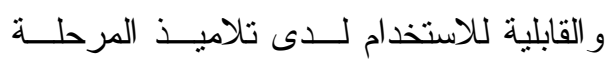

الإعدادية، وتوصلت نتائج الدر اسة إلى أنه لا لادئ

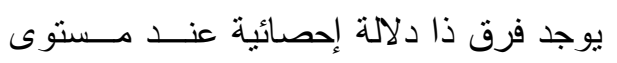

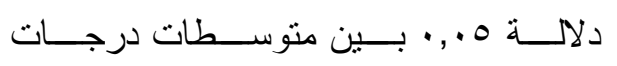

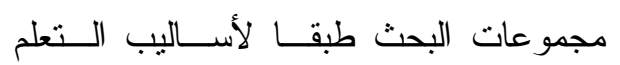

الحسية في القياس البعدي لاختبار التـــصيل لجديل

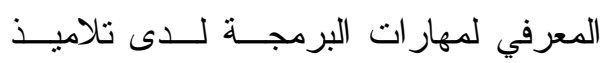

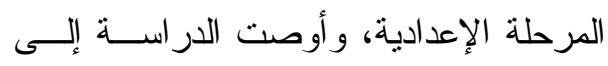

الاهتمام بزيادة الاتجاه نحو استخدام بيئـات الاعدات

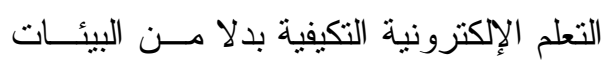

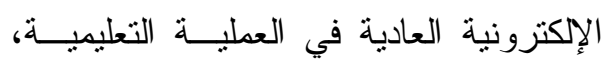

وضرورة مر اعاة المعايير الخاصة بتــصميم

بيئات التعلم الإككترونية التكيفية وفقا لأساليب

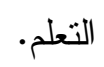

مما سبق تظهر الأهميــة المتز ايــدة

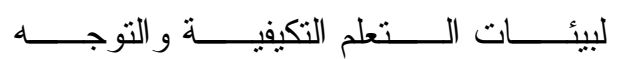

الكبير لاستخدامها بدلاً مــن بيئـات الــتعلم

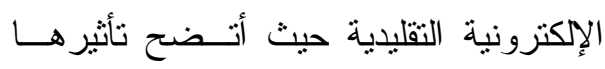

الواضح على التحصيل والأداء عند التلاميذ؛

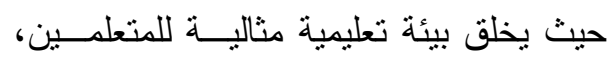

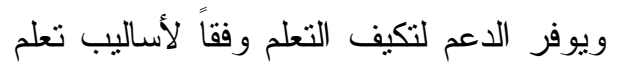

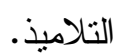

• إعتماد الجانب النظري علــى عناصــر

تصميم الموقف التعليمي وقــصور فـــي

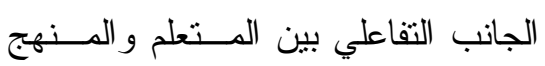

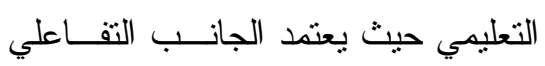
على إعداد بيئة تكيفية للطالب.

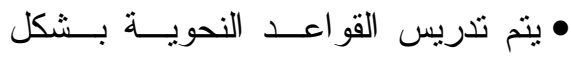

تقليدي، وأنه غير قائم على الاحتياجات

التعليمية الفعلية ولا ير اعي تمايز التعليم

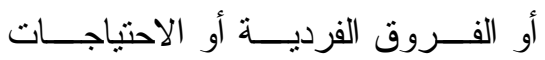

المعرفية و المهارية، وغير قــائم علـى لـى

استر اتيجيات تعليمية الكترونية حديثة.

ثالثًا : الإطلاع علـى نتــائج الاراســات

$$
\text { السابقة : السابة }
$$

• المحور الأول : الدراسات التي تناولت بيئة التعلم

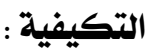

Sibel ) دراسة سيبل سـومويريك

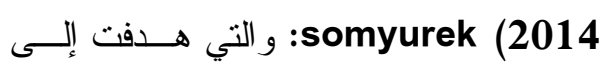

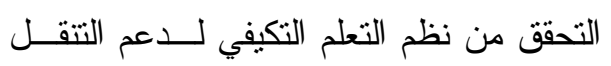

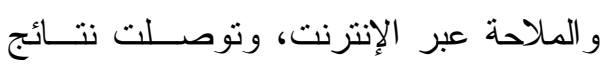

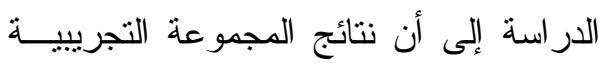

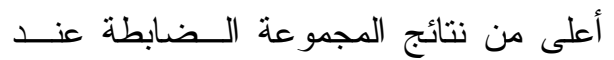

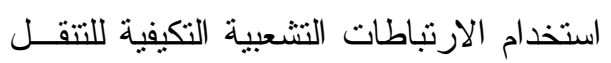

و الإبحار عبر الإنترنت، وأوصت الاراســـة

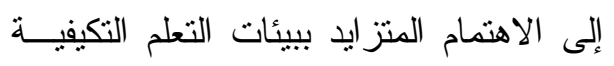

و التوجه إلى استخدامها بدلاً من بيئات التعلم

الإلكترونية التقليدية. 


\section{رابعاً : توصيات المؤتمرات والندوات :}

أكد المؤتمر الدولي الثــــي للجمعيـــة

العمانية لتكنولوجيا التعليم (T/ • ب) بعنوان:

تقتنيات البيئات التكيفية وتطبيقاتهـــا لتحقيــق تقنق متعة التعلم"، بــضرورة تطـــوير وتحــديث

مناهج

التعلم حتى تتو افق مع مفهوم تكيــف

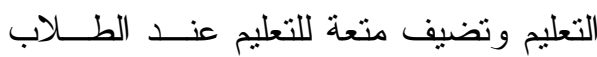
و المعلمين.

وجاءت توصيات مؤتمر تكنولوجيــا

الاتصالات و المعلومات وتطوير الأداء فــي موني

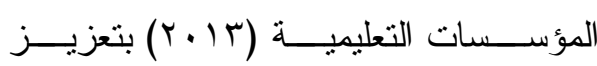

وتشجيع التعليم الإككتروني في المؤسـسات

التعليمية المختلفة، كما أكد على أهمية نوفير الإنير

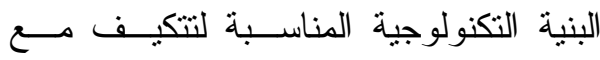

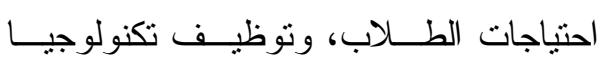
المعلومات في مؤسسات التعليم المختلفة، كما وهاب أةوصى بضرورة تحديث أساليب التـدريس

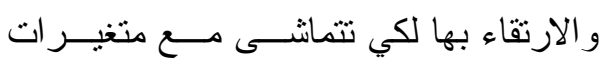

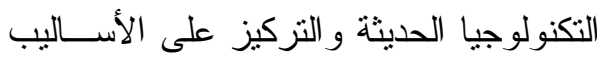
التدريسية و التي تكون قادرة على اسـتنيعاب

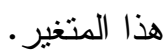

أكد أيضا المؤتمر العلمـي الـسنوي

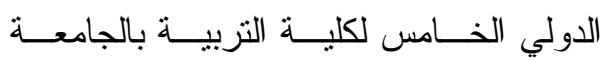

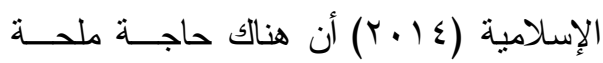

لتطوير العملية التعليمية بتوظيف باســتخدام

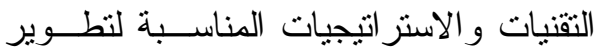

• المحور الــثاني: الدراسات التي تناولت

القواعد النحوية فــي اللغـــة العربيـــة

وصعوباتها:

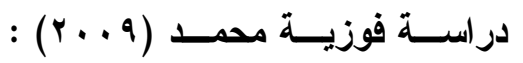

و التي هدفت إلى معرفة الأخطاء الــشائعة

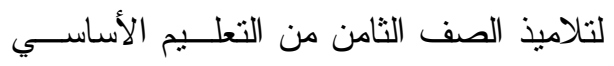

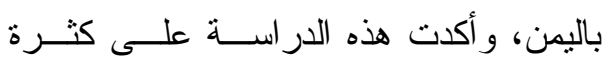

الأخطاء النحوية في كتابات التلاميذ المختلفة

أوصت الدراسة إلى أهمية اكتثاف الأخطاء

النحوية لاى الطلاب ومعالجتها .

دراسة ألفــت الجوجــو (11 + ب) :

و التي هدفت الكثتف عن فعاليــة تــدريس

النحو في ضوء نظرية الذكاءات المتعددة في

تنمية بعض المفاهيم النحوية لــدى طالبــات الصف السابع ضعيفات التحصيل، وتوصلت نتائج الدراسة إلى وجود فروق دالة إحصائياً بين المجموعتين في اختبار المفاهيم النحوية

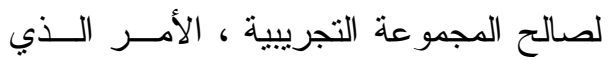
يؤكد فعاليـــة برنـــامج الــــكاءات المتعــددة أوصت الدر استة إلى أهمية تدريس المفــاهيم النحوية من خلال نظرية الذكاءات المتعددة . مما سبق تظهــر الأهميــة الكبيــرة

للكثف عن صعوبات تعلم القو اعد النحويــة

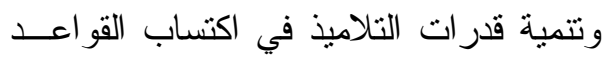

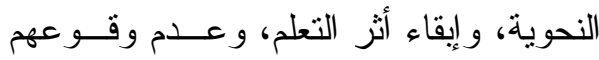

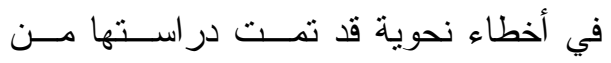

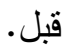


r . ما معايير تصميم بيئة تعلم تكيفية قائمة

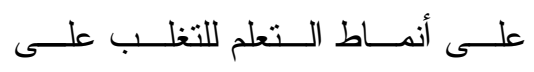

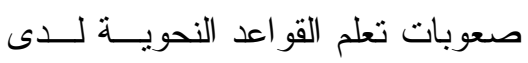
طلاب المرحلة الإعدادية ؟

r. ما التصميم التعليمي المقتــرح لبيئــة التعلم التكيفية القائمة على اســنر اتيجية

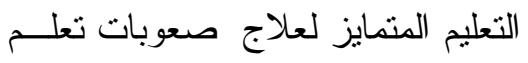
القو اعد النحوية لدى طلاب المرحلــــة الإعدادية ؟

ع. ما فاعلية بيئة تعلم تكيفية للتغلب على إعلى

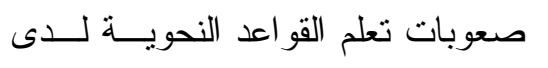
طلاب المرحلة الإعدادية ؟ أهداف البحث بهــدف البحث الحـالي إلـى عــلاج

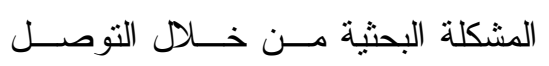
لتحقيق الهدف التالي :

- التعرف على أثز بيئة الــتعلم التكيفيــة القائمة على استر اتيجية التعليم المتـــايز

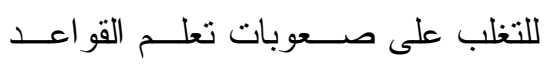
النحوية لدى طلاب المرحلة الإعدادية.

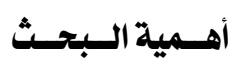

$$
\text { ترجع أهمية البحث الحالي إلى: }
$$

- قد يفيد هذا البحث المسئولين عن العملية

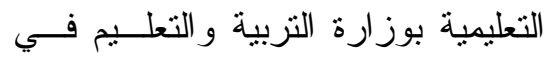
تطوير مناهج اللغة العربية بصفة عامة ومناهج القو اعد النحوية بصفة خاصــة مما يساعد في علاج صــعوبات تعلـــ
مهار ات المعلمين، فسوف تساهم في التأسيس

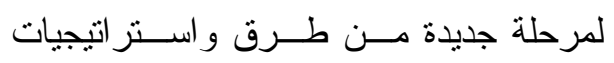

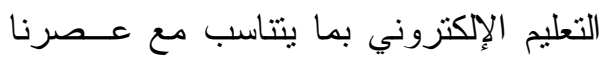
المتسار ع.

\section{مشكـلة الـبحــث}

مما سبق يمكن تحديد مشكلة البحـــث في وجود صعوبات تعلم القو اعد النحوية لدى

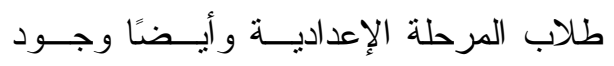
قصور في طرق التدريس المسـتخدمة فــي ولي تدريس القو اعد النحوية.

وهذا يسـستوجب اســتخدام الطــرق و الوسائل التكنولوجية الحديثـــة فـــي تعلــيم

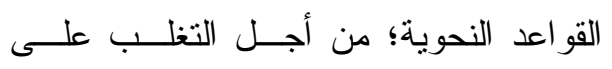
صعوبات تعلم القواعد النحوية، و الحد مــن لــن

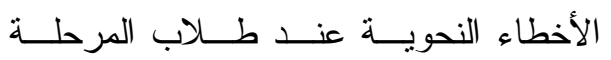
الإعدادية. ويمكن معالجة مشكلة البحــث مــن

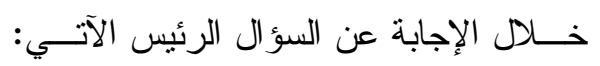

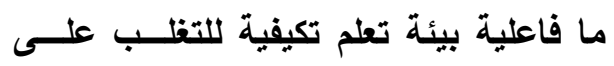

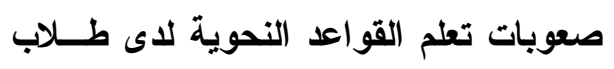
المرحلة الإعد ادية ؟ ويتفرع من هذا الــسؤال الــرئيس الأســـئة التالية: ا ـ ما الصعوبات التـي تواجــه طـلاب

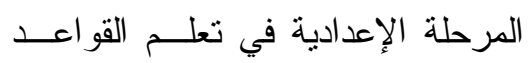
النحوية ؟ 
المعلمين في مر اعاة أساليب التعلم مــن

خلال بيئة التعلم الإككترونيــة التكيفيـــة القائمة على استر اتيجية التعليم المتـــايز

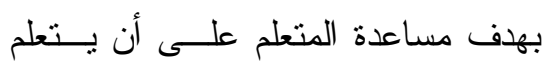
بفاعلية أكثر . حدود الـبحــث تمنتلت حدود البحث الحالي فيما يلي: - حدود موضوعية: تحديد موضــوعات

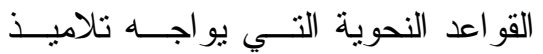

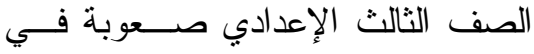
إكتسابها وتذكر ها كي يتم تدريس هــذه

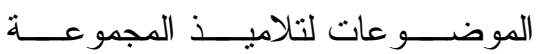

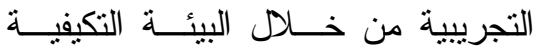
باستخدام استر اتيجية التعلبيم المتـــايز ، وتدريس هذه الموضوعات أيضاً لتلاميذ المجمو عة الضابطة بالطريقة التقليديــة،

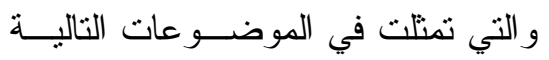

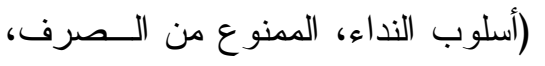
أسلوب المدح و الذم، البدل) في البيائــة التكيفية في ضوء اســتر اتيجية التعلــيم

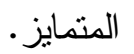

- حدود بشرية: تلاميذ المرحلة الإعدادية (الصف الثالــث الإعــدادي) وعـددهم

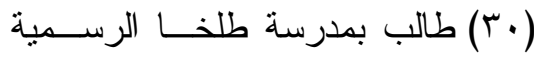
المتميزة للغات ب بإدارة طلخا التعليمية محافظة الدقهلية.
القو اعد النحوية لدى طــلاب المرحلـــة الإعدادية. - قد تساعد بيئة التعلم التكيفـي للقواعـــ

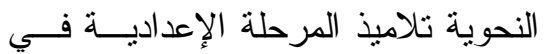
إكتساب قو اعد النحو العربـي بـسـولة وتوظيفها في كتاباتهم التحريرية ونطقهم من خلال تفاعل التلاميــذ مـــع البيئــة الإلكترونية التكيفية. - يُعد إضافة جديدة في تكنولوجيا تدريس

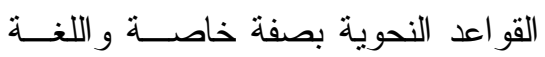

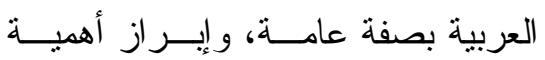
استخدام استراتيجية التعلــيم المتمــايز

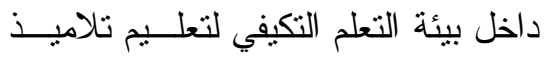
المرحلة الإعدادية القو اعد النحوية بشكل متع وبسيط. - تحسين تعليم القو اعد النحويــة لتلاميــذ المرحلة الإعدادية، و التصدي لصعوبات

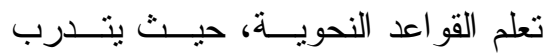
التلاميذ على در اسة القو اعد النحوية في

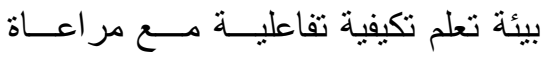

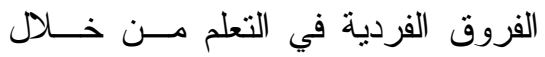
استز اتيجية التعليم المتمايز • - تقديم معالجة تربوية وتكنولوجيــة قـــ تساعد المعلمين فــي مر اعــاة أســاليب التعلم من خلال بيئــة الــتعلم الثقــديم

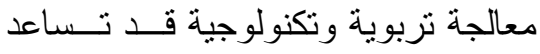




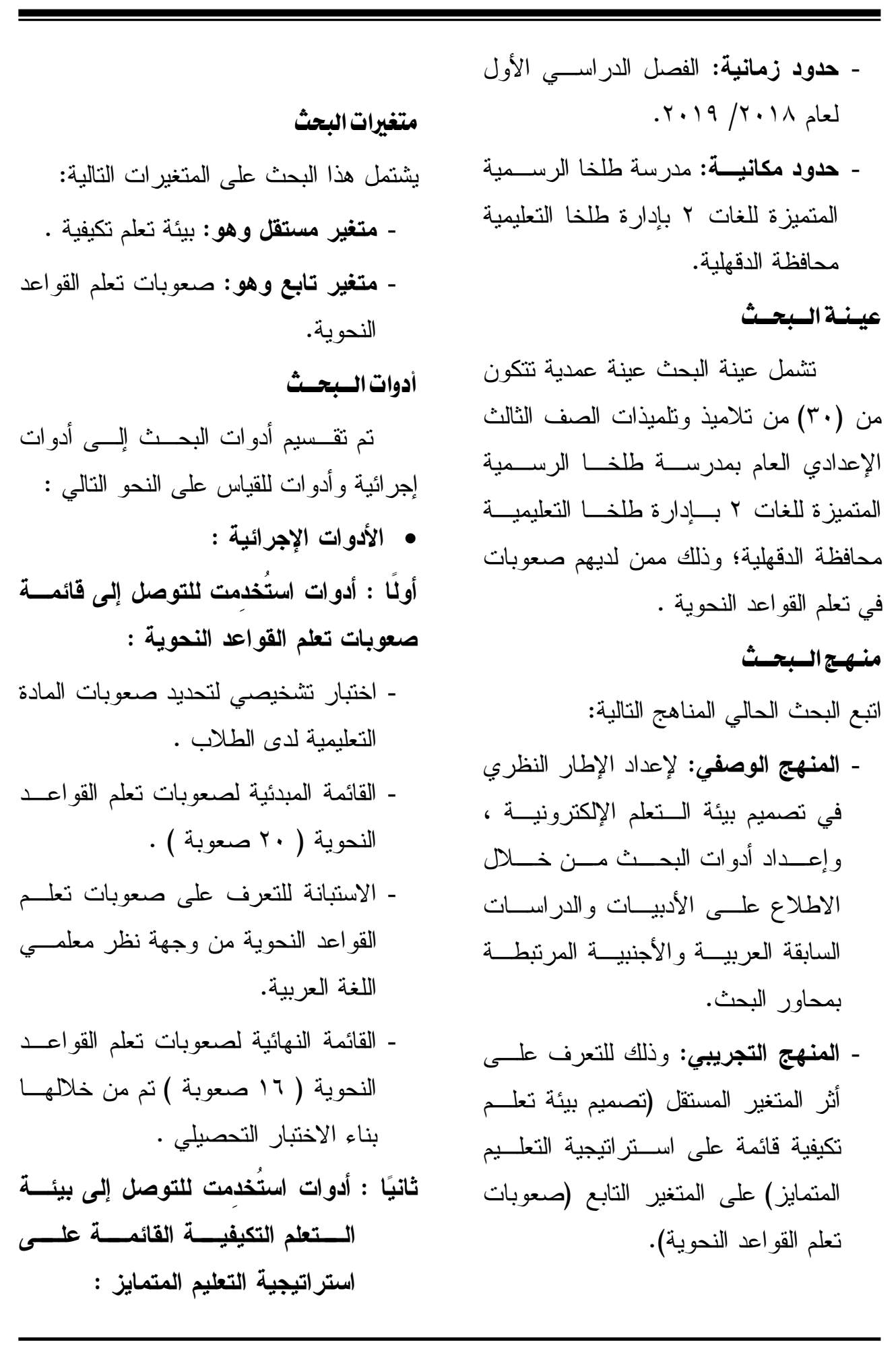




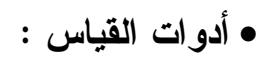

- قائمة معايير للبيئة التكيفية .

- اختبــار تحــصيلي لقيــاس الجوانـــب

- اختبار فارك ( Vark ) لتحديد أســاليب

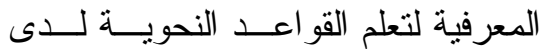

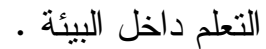

تلاميذ المرحلة الإعدادية.

\begin{tabular}{|c|c|c|c|}
\hline القياس البعدي & المعالجة & القياس القبلي & المجموعة \\
\hline \multirow[b]{2}{*}{ الاختبار التحصيلي } & الطريقة النقليدية & \multirow[b]{2}{*}{ الاختبار التحصيلي } & الضابطة \\
\hline & القائُة على استر اتيجية التعليم المتمايز & & يبية \\
\hline
\end{tabular}

التصميم التجريبي للبحث

اعتمد الباحث على التصميم التجريبي اجرايات البحث :

يتتاول الباحسث فـي هـــا المحسور

ذو التطبيق القبلي/البعدي

إجر اءات الدراسة، كذلك يتضمن إجــر اءات

جدول (التصميم التجريبي للبحث)

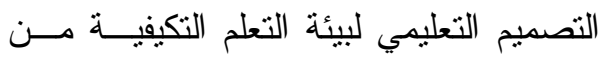

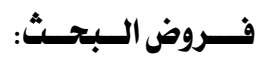

خلال نموذج (محمد الدسوقي، 10 • ب) وذلك بعد الإطلاع على العديد من النماذج، وفــي ضوء المعايير السابق تحديدها، وبناء أدوات البحث، وإجر اءات نتفيذ تجربة البحث، وفيما يلي العرض التفصيلي لذلك:

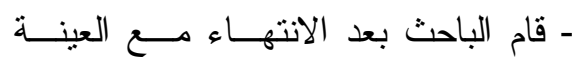

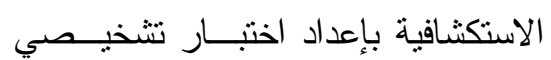

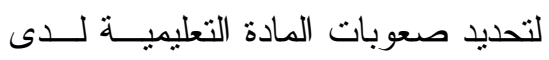

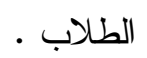

ـ قام الباحث بــاقتر اح القائهـــة المبدئيـــة - توجد فروق ذات دلالة إحـصائية عنــد

مستوى 2 ج •., • بين منوسطي رنب تلاميذ المجموعة التجريبية والــضابطة في التطبيق البعدي للاختبار التحــصيلي

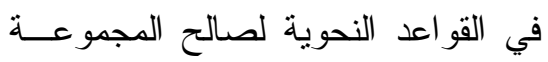

$$
\text { التجرييية }
$$

- يوجد فرق دال إحصائيــــا عند مستوى

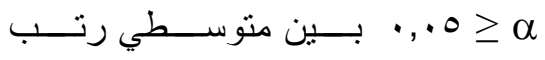

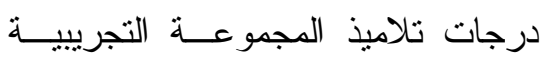

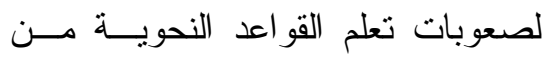

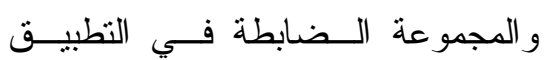

خلال ما تعرض له من نتائج للاختبــار

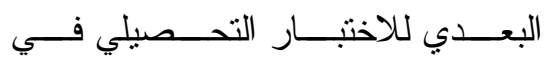

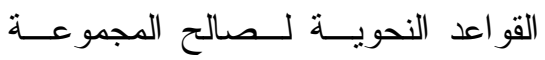

التجريبية. 
- قبل بدء عينة البحث في استخدام بيئـة التعلم التكيفية ، تم التطبيق القبالــي لأداة

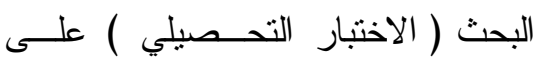
النحو التالي : - النحت

- بعد توجيه خطاب إلى مدير إدارة طلخا التعليمية بخصوص نطبيق تجربة البحث على بعـض تلاميــذ الــصف الثالـــث الإعدادي و الحصول على موافقته ، قام الباحث بتطبيق تجربـــة البحــث قبليًأ بالفصل الدراســي الثـاني مــن العــام

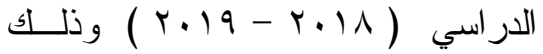

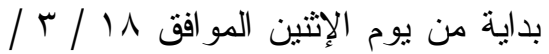
9 1 أبم على جميع أفراد عينة الدراسة الأساســــية للمجمــــوعتين الـــــابطة و التجريبية ، وبعد الإنتهاء من تطبيـق

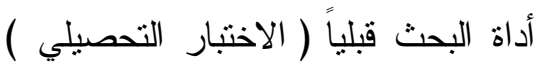
على عينة البحث تم رصــد الــدرجات تمهيدًا لإجر اء المعالجات الإحصائية.

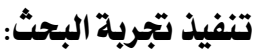

تم إنباع الأتي لإجر اء تتفيــــ تجربـــة

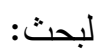

أ) إجراء جلسة تحضرية : قام الباحــث بإجر اء مقابلة تعريفيــة مـــع تلاميــذ الــصف الثالــــث الإعـــادي (عينـــة

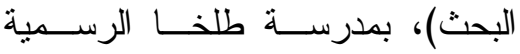

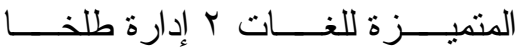
التعليمية، وذلك يوم الثثلاثاء المو فــق

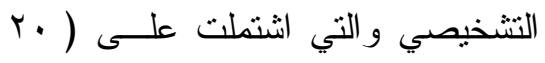

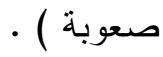
ـ تم تحويل القائمة المبدئيــة لــصعوبات

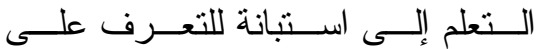
الصعوبات النحوية مــن وجهــة نظــــر معلمي اللغة العربية ، وتم تحكيمها

- تـــم التوصــل إلــى القائمـــة النهائيـــة لصعوبات تعلم القو اعد النحوية و التــي لـوني

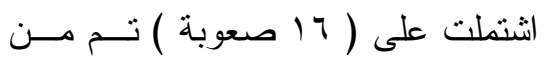
خلالها بناء الاختبار التحصيلي . - نم اعداد الاختبار التحصيلي من خــلال

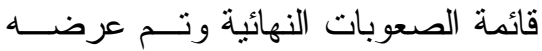
على المحكمين .

- تم تتسيق عينة البحث تشمل عينة عمدية

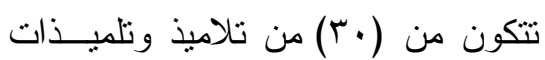
الصف الثالث الإعدادي العام بمدرســـة الثئ طلخا الرسمية المتميزة للغات ب بـإدارة

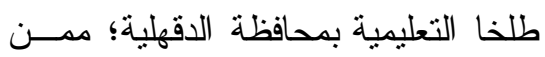

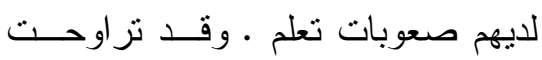

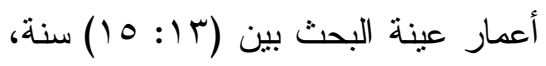

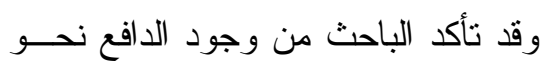
التعلم و التدريب و الرغبة نحو التعلم، وتم

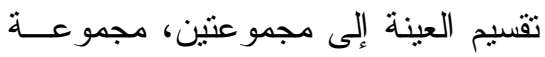
تجريبية تتكون من (10) تلميذ وتلميذة،

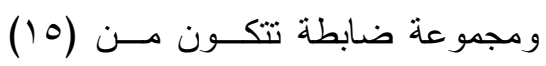
تلميذ وتلميذة . 
توجيهمخ إلـى المحتــوى المناســب

لنمطهم وفقًا لنتيجة الاختبار ( سمعي

$$
\text { ، بصري ، حركي ) }
$$

- تم متابعة المتعلمين (عينة البحــث)

و الرد علي مشاركاتهم، وتــصحيحها،

وتوجيهرم إلكترونياً من خلال البيئــة،

وكـــللك متابعـــة غرفـــة الحـــوار

و المحادثات، و الرد علي رسائل البريد

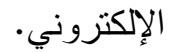

- ت تم متابعة إجابات المتعلمــين (عينــة

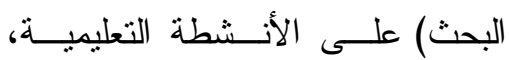

وتوجيهم للإجابات الصحيحة، وتقديم

$$
\text { الاعم لهم. }
$$

- نم تتظيم الحوار بين المتعلمين (عينة البحث) داخل غرف الحــوار وأثتـــاء

$$
\text { المحادثات من قبل الباحث. }
$$

\section{التطبيق البعدي للاختبار التحصيلي :}

بعد إنتهاء تتفيذ التجربة الأساسية بييئة

التعلم التكيفية القائمة على استر اتيجية التعليم

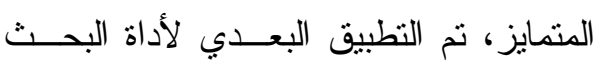

$$
\text { ( الاختبار التحصيلي ) على النحو التالي: }
$$

تم تطبيق الاختبار التحـصيلي يـوم

الثلاثاء المو افق 9 / ـ / 9 / ـ بم على عينة البحث ، وبعد الإتتهاء من تطبيق أداة البحث

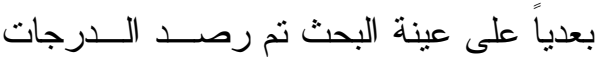

$$
\text { تمهيدًا لإجر اء المعالجات الإحصائية . }
$$

9 / / / 9 / إم، وقام بتوزيع ر ابط

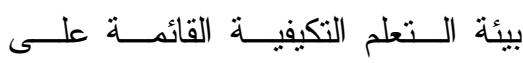

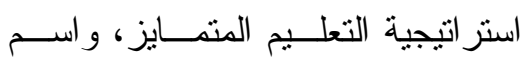
المستخدم، وكلمة المرور الخاصة بكل متعلم، وتم توضيح خطوات الــدخول

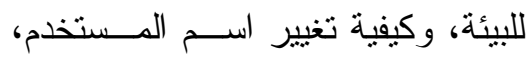

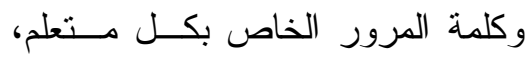

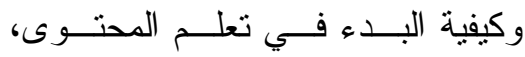
و الإطلاع على تعليمات كل مــديول، و أهدافه ومحتوى التعلم الخــاص بـــه،

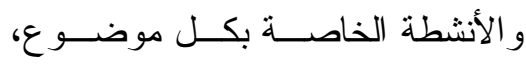
وكيفية استخدام أدوات التفاعل المتاحة

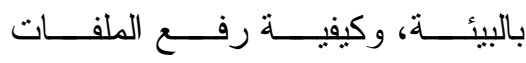
ومشار كتها. ب) تنفيذ التجربة الأساسية للبحــث: تـــ تتفيذ التجربة الأساسية للبحث خــلد

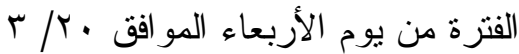

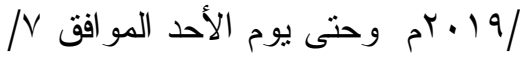

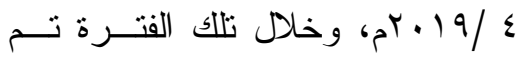

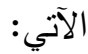
- تم متابعــة عمليــة تـسجيل دخـول المتعلمين (عينة البحث) لبيئة الــتعلم التكيفية القائمة على استر اتيجية التعليم المتمايز بشكل يومي، ومستمر طوال فترة النطبيق. - متابعة إجر اء المتعلمين لاختبار تحديد

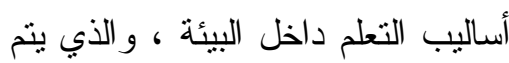


ويشير نبيل جـاد عزمــي ومسروة

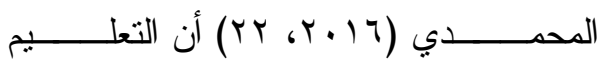
الإلكتروني التكيفي نوع من أنــــواع الــتعلم

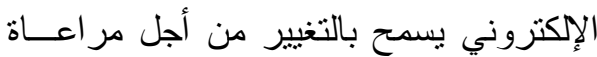

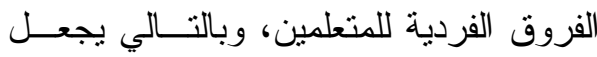

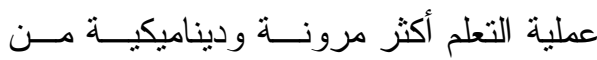

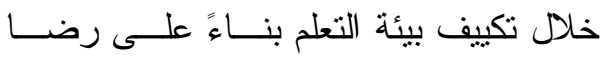

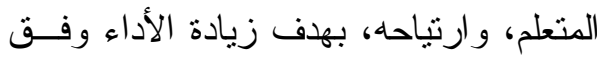

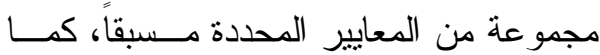

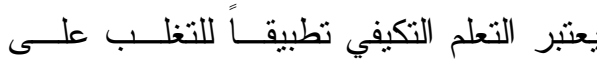

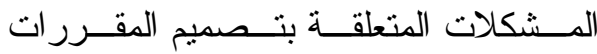
الإلكترونية، و التي كانت نقدم المحتوى بشكل و احد يناسب الجميع، كما تسمح حلول التعلم

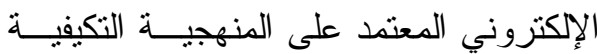

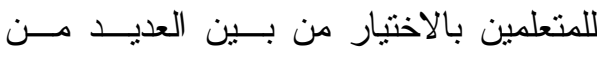

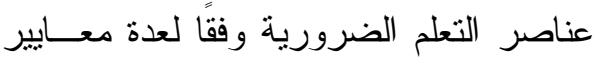
مختلفة.

ومن خلال ما سبق يتضـح أن التعـــيم

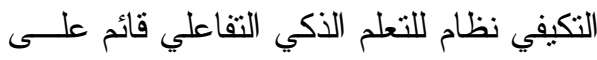
تكيف المحتوى، حيث بركز على كيفية تعلم

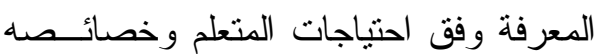

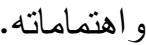
عناصر بيئة التعلم التكيفية : وتتنمل على العناصر التالية:

- نموذج المحتوى Content model: يثشير إلى الطريقة التي يتم فيها تتظـــم

\section{الإطار النظري للبحث :}

Adaptive مفهوم بيئة الــتعلم التكيفيـة : Learning يعرف إسيتشاكول و لامنوي وبيتششتر

Esichaikul \& Lamnoi \& Becher, )

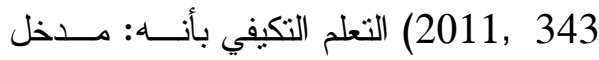
جديد للتعليم حبــث يجعـل نظـــام التعلــــم

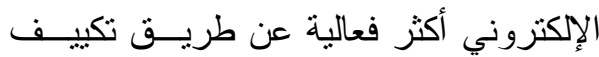

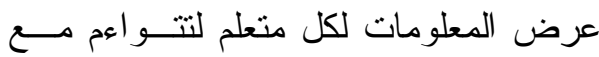
معارفه، فالتعليم التكيفي يقوم على افتـــر اض

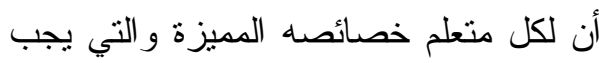

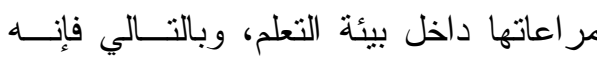
يعمل على تطوير عمليــة الــتعلم وتحـسـين

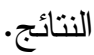

Matar, 2014 , ) ويسشير ماتـــار

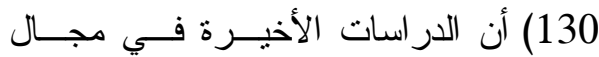

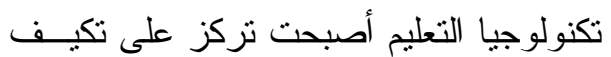

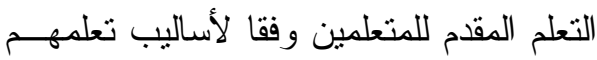

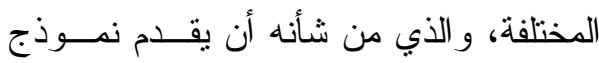
تربوي جديد قائم على منهجية تكيفية للتغلب على مشكلات الدر اسات الــسابقة بتــصميم المقررات الإلكترونية، حيث تتيح المنهجيـــة

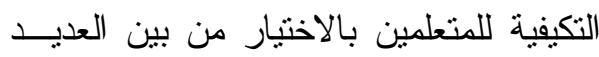
من العناصر وفقاً لعدة معايير مختلفة: خبرة

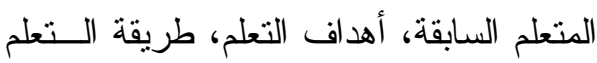

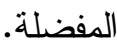




$$
\begin{aligned}
& \text { 口ـ المرحلة الثانيـة (مرحلـة الإنتـــاج } \\
& \text { Production stage } \\
& \text { المرحلة يتم مو ائمة كينونــات الــتعلم }
\end{aligned}
$$

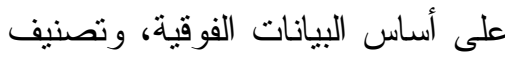

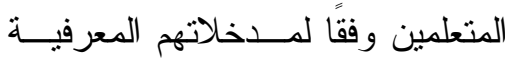

$$
\begin{aligned}
& \text { و المهارية و الوجدانية وأساليب تعلمهم }
\end{aligned}
$$

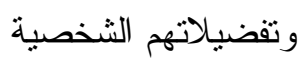

$$
\begin{aligned}
& \text { المرحلة الثالثة (مرحلة الاســتخدام } \\
& \text { Phase of use }
\end{aligned}
$$

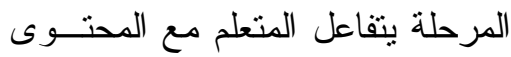

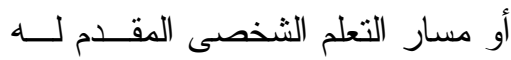

$$
\begin{aligned}
& \text { وفقًا لخصائص المــتعلم الشخــصية، } \\
& \text { وخلفيته السابقة، ومستو اه التعليهـي، } \\
& \text { ومعارفه ومهار اته، وتفضيلاته فـى ومنى } \\
& \text { العرض و الإبحـــار بعناصــر الــتعلم }
\end{aligned}
$$

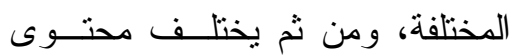

$$
\begin{aligned}
& \text { المقرر المقدم من حيث البنية المعرفية } \\
& \text { و المهارية من متعلم لآخر • } \\
& \text { ويتم حفظ المحتوى التعليمى التكيفــي } \\
& \text { وكينونات التعلم في قو اعد على الويب تسمى } \\
& \text { المستودعات الرقمية، وهى ليست مستودعات } \\
& \text { حفظ أرشيفية حيث لا ينطبق عليها معسايير }
\end{aligned}
$$

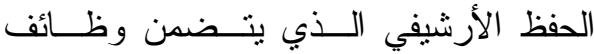

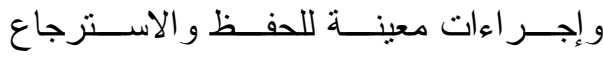

$$
\begin{aligned}
& \text { و التداول، ولكنها مستودعات للحفظ الآمـن } \\
& \text { للمعلومات الرقمية، وبعد الانتهاء من تصميم }
\end{aligned}
$$

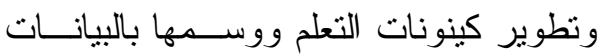


التعلم، وتعد أساليب الــتعلم هـــي أحـــ

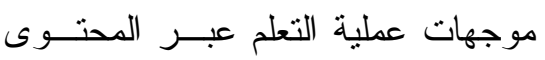

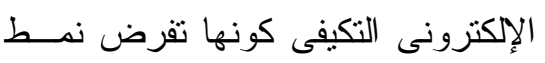

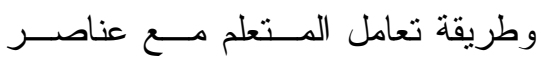

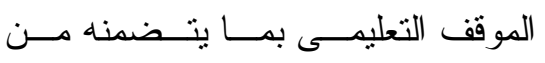

عناصر منتوعة، ويعتمد تصميم نموذج بن

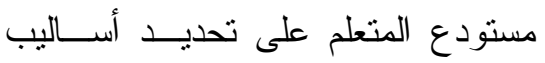

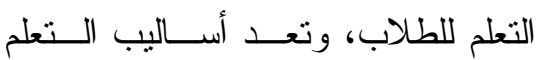

سمات شخصية معرفية تتمو لدي الأفر اد

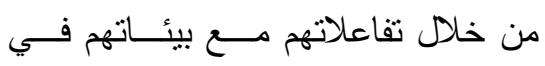

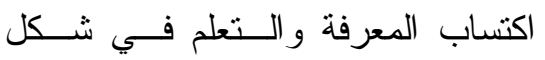

عادات، وتظهر هذه الأساليب في شكل

تفضيلات لدي المتعمين فــي عمليـات

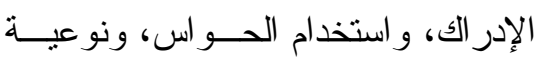

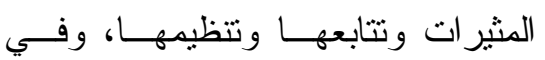

عمليات استيعاب المعلومات ومعالجتهــا

في بنيات معرفية في الجهاز المعرفي

و الذاكرة، وكما نظهر فــي تفـضيلاتهم

المتصلة بأساليب اتخاذ القرار ، وتفضيل

الطرق و الأســاليب و الخبــرات التـي لتئي

$$
\text { يتعلمون منها. }
$$

ولعل هناك عديـــــــن المحــاو لات

لعلماء النفس فى الاهتمام بتصنيف أســاليب

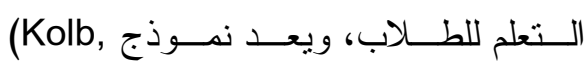

1984,210)

لأنماط تعلم الطلاب، ويدور نموذج "كولــبـ"

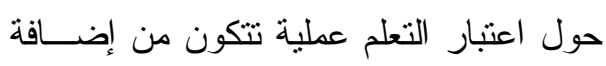

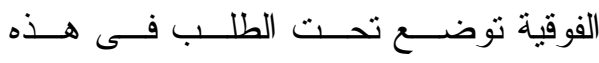

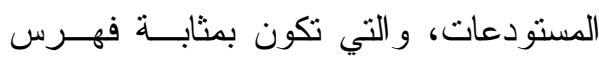

مصنف لكينونات التعلم على أساس البيانـات بـات

الفوقية لاستدعائها و استخدامها في تــصميم

التعلم حيث يستخدم المـصمم أدوات تــأليف

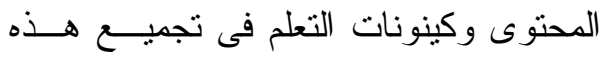

الكينونات في موديو لات و إنــشاء كينونــات

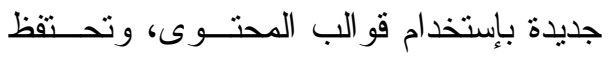

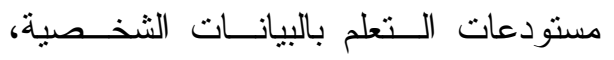

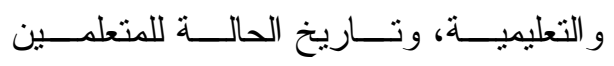

الذين يستخدمون هذه المسـستودعات، كمـــا

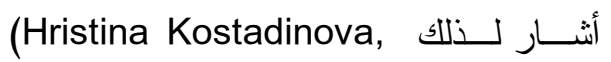

George Totkov, Hristo Indzhov,

.( 2012, 97

- تصميم نموذج مستودع المتعلم: يـشير

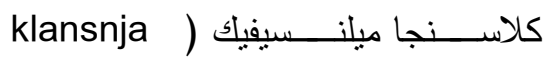

إلى (Milicevie, 2011, 763-768

أن بيئات التعلم التكيفية لا تحتوى فقط

على مستودعات رقمية لعناصر الـتنعلم

المختلفة، ولكنها أيضاً تتضمن مستودئ لفناصرع

لنمـاذج المـتعلم learning Models

Repository

المستودع الخبرات الــسابقة للمتعلمــين

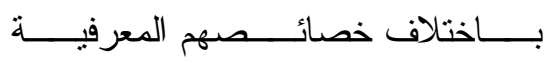

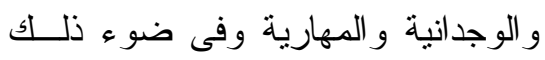

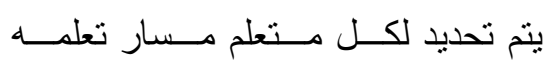

و المحتوى المناسب له مــن كينونــات 
للمحتــوى بــصدد در اســتنه، ومـــدى

المعلومات و المهار ات المتـــوفرة لديـــه

باســـتخدام اختبــــار ات قــــيرة ولهــــا تدريجات: مـــخفض جــــاً، مــنخفض،

متوسط، جيد، ممناز ، وفي ضو ء الدرجة

التى يحققها المتعلم يبدأ مـســار تعلمـــه الشخصى للمحتوى.

• المكون الرابع (سجل المتعلم Learner

Record

أجر اها المتعلم فىى در اســته للمحتــوى،

و الوسائط التي اســتخدمها، و الــدرجات

التي حققها في الاختبار ات، و المهـــار ات

التي أداها وكيفية تأديتها و الــصعوبات

التى واجهته، ومدى تمرسه في استخدام

مصادر الإنتزنت، و المواقع التي استعان

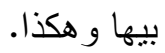

- تصميم المحتوى التكيفى فـي ضــو أساليب التعلم:

نظراً لأن نظم إداره التعلم الإككتروني لا يمكنها تقديم المحتوى الشخصي لكل متعلم

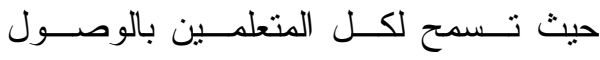
إلى نفس المحتــوى دون مر اعـــاه الفــروق ن. بينهم في المستوى المعرفـى و الاهتمامـــات و الأفعية والأهداف؛ أي تكيــف المحتــوى

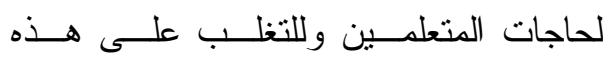
المشكلة.
خبرات معرفية، فهو بري أن التعلم عمليــة دائرية يمر فيهـــا المــتعلم مـــن الخبــرات المحسوسة تتبعها عمليـــة نقــلـ بالماحظـــة و التأمل وهذا يؤدي بدوره إلي تكوين المفاهيم المجردة، و التعميمات مــن مو اقــف الفهـــ المجرد التي يتم اختبار ها في مو اقف جديــدة عن طريق التجربة و العمل، وعلي المتعلم أن يكمل هذه الدورة ليمر بهذه المتتابعــة مسـن الخبر ات، ورذا ما يوضحه الشكل التخطيطي

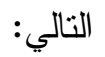

وفى ضوء ما سبق يمكن القــول أن

تصميم مستودع نماذج المتعلم يعتمد علـى أربعة مكونات رئيسية وهي:

• المكــــن الأول (الهويــــة Identity):

ويعرض فيه معلومات عـن المــتعلم، ومرحلته العمرية.

• المكون الثاني (التفضيلات الشخــصية

\section{:(Personal preferences}

ويعرض فيه نمط الوسائط التى يفضلها

المتعلم لعــرض المعلومـــات، ألـــوان

النصوص وخلفيات الــصفحات، نمـــ

الإبحار و العرض للمعلومات، وفى هذا

الجانب يتم تحديد أيضـاً أســـلوب الــتـعلم

المفضل لاى المتعلم.

• المكون الثالث (القدرة Ability): وفي

هذا الجانب يــتم قيــاس فهـــم المــتعلم 


$$
\begin{aligned}
& \text { المقياس: منخفض جــداً، مــنخفض، } \\
& \text { متوسط، جيد، ممتاز . } \\
& \text { وقدم مقياس ماير وبريجز - Myers } \\
& \text { Briggs Type Indicator (MBTI) } \\
& \text { 口 الوجه الرابع: (التاريخ) ويسجل كــل } \\
& \text { تصميم نموذج جديد للمحتوى التكيفى يقـوم } \\
& \text { شىء عن المتعلم: التجو ال و المصادر . } \\
& \text { • نموذج المجال Domain model: قـــــ }
\end{aligned}
$$

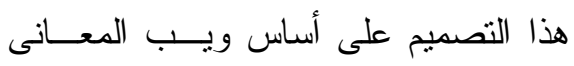

$$
\begin{aligned}
& \text { الدلالية حيث يمكن للأجهزه المختلفة تبادل }
\end{aligned}
$$

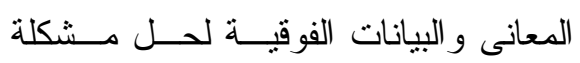

$$
\begin{aligned}
& \text { البحث عن المعلومات، ويدور هذا النموذج } \\
& \text { حول أساليب التعلم و اشتمل على عدة أوجه }
\end{aligned}
$$

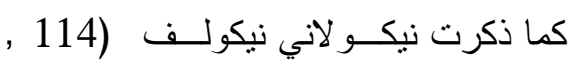

$$
\begin{aligned}
& \text { (Nikolany Y. Nikolaev, } 2013 \\
& \text { وهي: } \\
& \text { 口 وجه المعاني Meanings: ويـساعد } \\
& \text { فى تمثيل مصادر التعلم حسب الأفكار } \\
& \text { فى شكل موديو لات مختلفة وتمنل كل }
\end{aligned}
$$

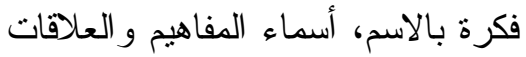

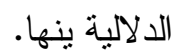

$$
\begin{aligned}
& \text { ص وجه البيانات الفوقيــة metadata: } \\
& \text { للتأكد من أن البيانات الفوقية (المؤلف، }
\end{aligned}
$$

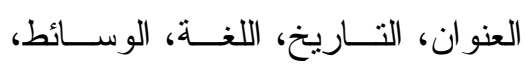

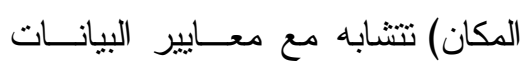

$$
\begin{aligned}
& \text { الفوقية لكينونات التعلم. } \\
& \text { 口 وجه الفـئة Category: ويسـساعد } \\
& \text { في تصنيف المصادر في فئات: مقدمة، } \\
& \text { أمثلة، تعريفات، توضيحات، تدريبات. }
\end{aligned}
$$

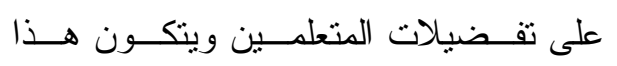

$$
\begin{aligned}
& \text { النموذج من ثلاثه نماذج (إير اهيم الخمـيس، ولئ }
\end{aligned}
$$

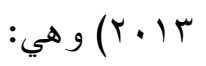

$$
\begin{aligned}
& \text { • نموذج المتعلم Learner model: اعتمد } \\
& \text { هذا النموذج على النظرية المعرفيــة فــي } \\
& \text { وصــف صــفحة المــتعلم و التفــيلات } \\
& \text { التعليمية ووصف المتعلم طبقـــا لأربعــة } \\
& \text { أوجه: - (أنعين } \\
& \text { ص الوجه الأول: (الهوية) ويستخدم فـي }
\end{aligned}
$$

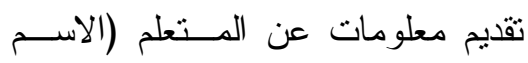

$$
\begin{aligned}
& \text { الأول - اسم العائلة - الدخول - نوع } \\
& \text { (الوسائط). } \\
& \text { ص الوجه الثاني: (التفضيلات) ويـستخدم }
\end{aligned}
$$

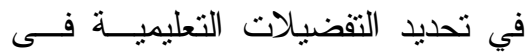

$$
\begin{aligned}
& \text { ضوء نموذج مايرز - بريجز : تعلــيم } \\
& \text { كامل "T" البدء مباشرة فى المهمة "F" }
\end{aligned}
$$

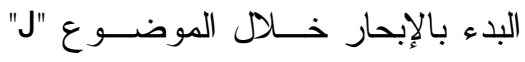

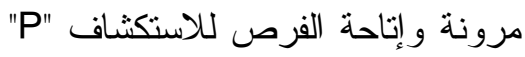

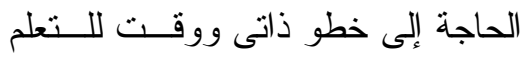

$$
\begin{aligned}
& \text { "L" تعليم سريع "L" } \\
& \text { 口 الوجه الثالث: (القدرة) وتستخدم فـى } \\
& \text { تقديم وقياس درجة فهم المتعلم للمفهوم }
\end{aligned}
$$

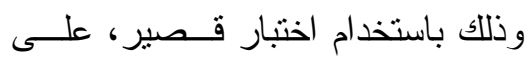


عناصرها بشكل منو ازن مــع طبيعـة

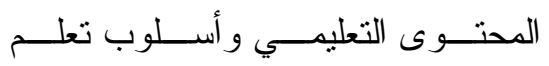

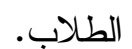

• التكيف القائم على التعلم التفاعلي: تتم فيه عملية التعلم بطريقة ديناميكية تكيفية لشرح المحتوى التعليمي بعـدة طــرق

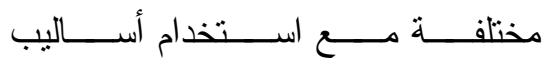
و استر اتيجيات التفاعل المناسبة. • التكيف القائم على المحتوى: فيه تغيـر المصادر و الأنشطة من محتو اها بطريقة

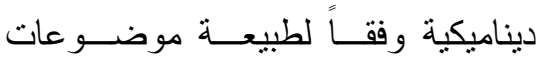
المحتوى و الأسلوب التعليهي للطلاب. وتتفق الدراسات و البحوث علــى أن نظم التعلم التكيفي هي نتاج للامج بين خمس تكنولوجيات للأكاء الاصطناعي وهي: نظام التوجيه الــــكي، ونظـــام الوســـائط الفائقـــة التكيفي، وتصفية المعلومات التكيفية، و التعلم التعاوني الذكي، و المر اقب الذكي. فالتعلم التكيفي القائم على الويب هو نظام تعليمي إلكتروني يهذف إلـى محاكــاة

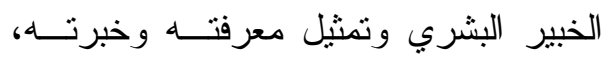

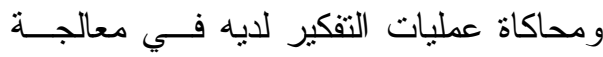

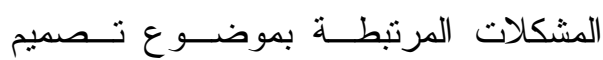

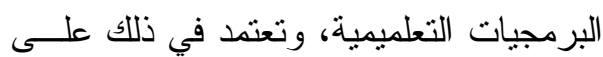

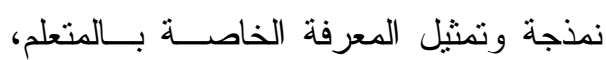
ولذلك تعد نظم التعلم التكيفي حلاً بديلاً للتعلم

\section{ص وجـهـ أســلوب الــتعلم Learning}

method الاعتبار عند اختبار المصادر.

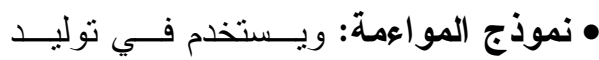
المحتوى المخصص وتطبيق قو اعد البنيـــة و العرض حيث يقوم بالبحث عن المصادر و اختبار المناسب منها.

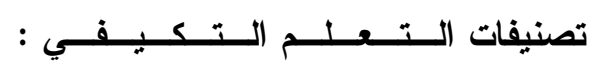

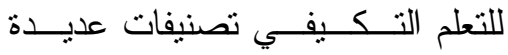

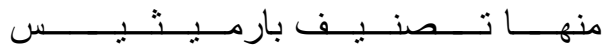

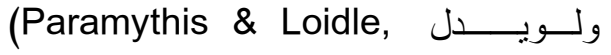

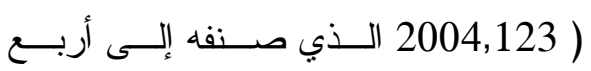

$$
\begin{aligned}
& \text { مجمو عات وهي: } \\
& \text { • التفاعل التكيفي. } \\
& \text { • توزيع المقرر التكيفي. } \\
& \text { • استكثناف المحتوى وتجميعه. } \\
& \text { • الدعم التعاوني التكيفي. }
\end{aligned}
$$

كما حددا أربعة نماذج لهذه البيئة، وهي: المجال و المتعلم و المجمو عة ونموذج التكيف.

بينما يـصنفه بــورجز، وتاترسـل (21, (Burgos \& Tattersal, 2006 ثلاثة أنماط : • التكيف القائم على واجهــة التفاعـلــ

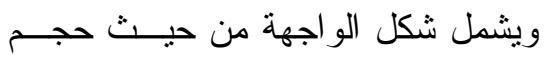

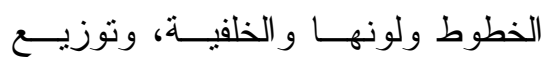


مبررات الاهتمام بصعوبات التعلم:

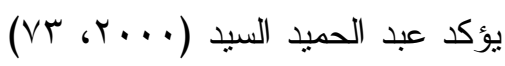
إن الاهتمام بصعوبات التعلم تعد خطوة نحو

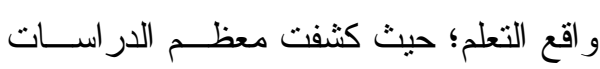

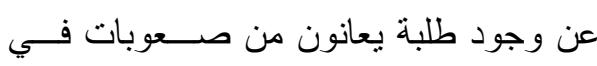

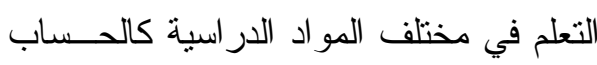

$$
\text { و القر اعة و القو اعد النحوية و غير ها. }
$$

دور المعلم في علاج صعوبات تعلم القو اعد

النحوية: - دور النمب

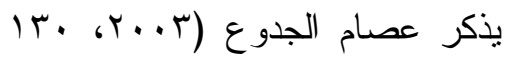

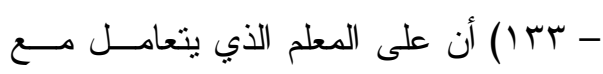

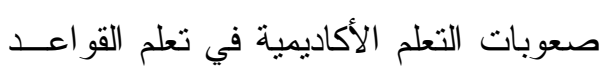

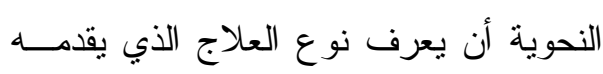

للطالب، ومن الخطوات التي يجب أن يتبعها

$$
\text { المعلم: }
$$

• توفير أفضل بيئة تعليميــة: يجــب أن

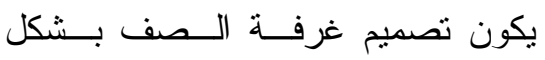

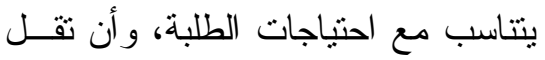

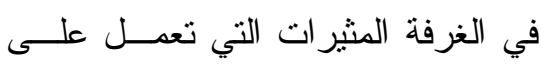

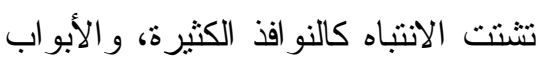

المفتوحة، والابتعاد عن الأمــاكن التـي لتئي

$$
\text { تزدحم فيها حركة المرور . }
$$

\section{• تزويد الطالـب بالتعليمــات اللازمــة}

و الواجبات المطلوبة: يجب أن يعطـي لئي

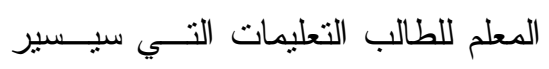

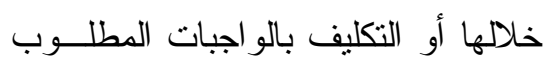

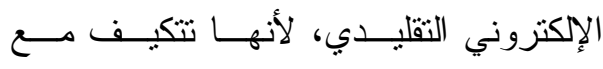

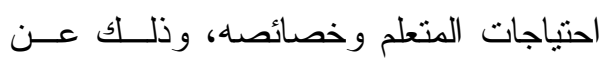

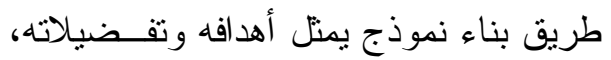

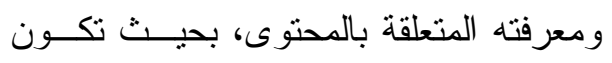
أكثر ذكاءً عن طريق إدخال وتتفيذ الأنشطة التي يقوم بها المتعلم. مفهوم صعوبات التعلم:

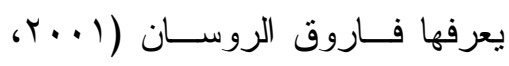
ـ • r) على أنها: "اضطر ابات في العمليــات العقلية أو النفسية الأساسية التي تشمل الانتباه و الإدر الك، وتكوين المفاهيم و التذكر، وحسل

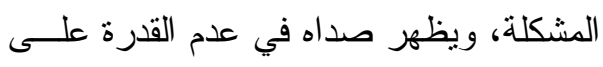
تعلم القر اعة و الكتابة و الحساب، وما يترتــبـ

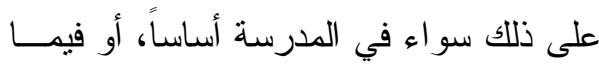
بعد من قصور في تعلـــم المـــو اد الدر اســـية المختلفة".

ويستخلص الباحث تعريفها إجرائيـا

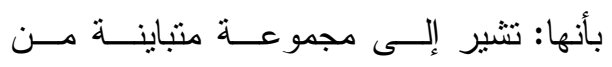
الاضطر ابات تؤدي إلى ضعف مستوى أداء

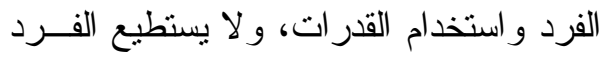

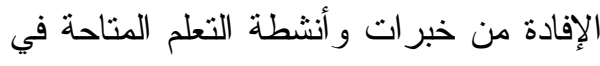
حجرة الدراسة أو خارجها، فهي ليست تخلفًا

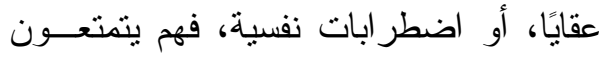
بذكاء منوسط ولكنهم لا يسنطيعون الوصول

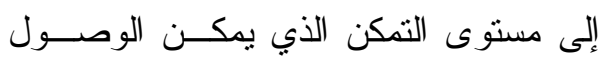
إليه. 
خلال متابعة المعلم كما هو محـــور البحــث

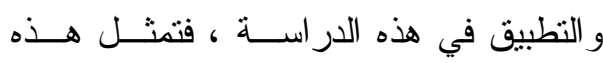
الدر اسة محور ا مهما لحل مــشكلة صـــوبة

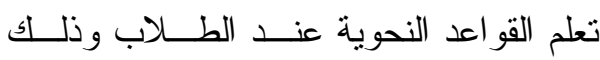
باستخدام أسايب تكنولوجية تشويقية تجعـل المحتوى يلائم كل متعلم، بحيث بيتعد المعلم

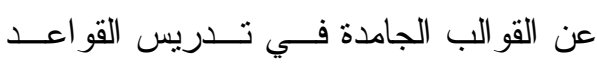
النحوية؛ لأن هذه الطر ائق لا تساعد الطلاب على تشكيل ملكاتهم اللغوية العلمية التي لابد منها، ومن خلال هذه الدر اسة التي تشير إلى تصميم بيئة تعلم تكيفية تدعو إلى التتوع في طر ائق التدريس باستخدام التعليم المتثــايز ، حيث ستر اعي الفروق الفردية بين الطــلاب،

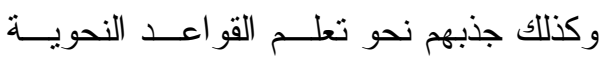
بوسائل تعليمية شــيقة داخــل بيئــة الــتـعلم التكيفية.

نتائج البحث ومناقشتها :

يختص هذا الجزء بالإجابة عن أسئلة

البحث في ضوء اختبار صحة الفروض من

عدمها، وفيما يلي العرض التفصيلي لذلك:

( ) الإجابة عن السؤال الأول: للإجابة عن

السؤال الأول من أسئلة البحث وهو: "ما

الصعوبات التي تواجه طلاب المرحلـة

الإعدادية في تعلم القواعد النحويـــة؟"،

وتم الإجابة عن هذا السؤال في فــصل

إجراءات البحث وتحديداً في ملحق (r)، وذلك نظر اً لكونه سؤ ال إجر ائي.
منــــهـ أدائهـــــا وأن نكــــون التعليمــــات و الإرشادات و اضحة، كما عليه أن يتأكد من فهم الطالب للتعليمات. • تصنيف أنواع السلوك: يجب أن يتبـع المعلم قو اعد النظام و أسسه الو اضــــة المفهومة، وأن يكون عند تطبيقها أقرب إلى الثبات و القوة، وأن يكون في تعامله معه معلمًا وربيًاً وليس موبخًا و معنفًا، و أن يكون رد فعله على نجـــاح وتقـــدم الطالب إيجابيًّا، و أن يحــتفظ بإتز انـــهـ و هدو عه أثناء أي نقاش.

• رفع المعنويات وتقرير الأت: إن بنــاء

كيان الفرد أمر هام من و اجب المعلــــ، أن يكافأ الطالب على تقدمه و إنجاز اتـــه بأسلوب معتدل بعيد عن التطــرف، وأن ينتزز كل فرصة ممكنة تـشجعه علـى بـى الإنجاز وتحفزه على العمل وتعزز ثقته بنفسه وبقدر اته مهما كانت بسيطة فـي نظر الآخرين، و أن يكون على اتـصال

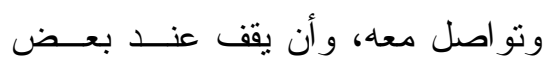
المشاكل للوصول إلى حلول.

ويرى الباحث أنه على معلمي اللغـــة العربية الانتباه لما أثرنا إليه وتتويع طــرق تدريس القو اعد النحوية بما يناسب المتعلمين من خلال البيئة التكيفية التي تلائم كل متعلم حيث يستطيع التعلم من خلالها و التفاعل مع

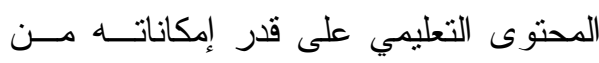


الإجابة عن هذا السؤال فـي ضــوء اختبار صحة الفروض التالية : الفرض الأول:

تم اختبار صحة الفـرض الأول مــن

فروض البحث، والذي نص على أنه: "توجد

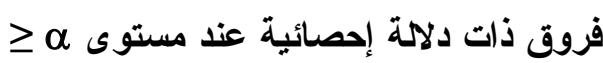
ه ., . بين متوسطي رتب تلاميذ المجموعة دلآدة

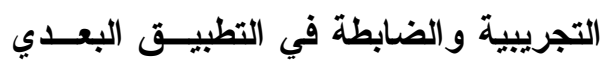

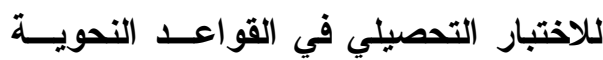
لصالح المجموعة التجريبيـة"، و لاختبـــار صحة هذا الفرض تمت المعالجة الإحصائية

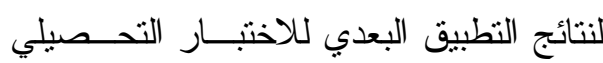

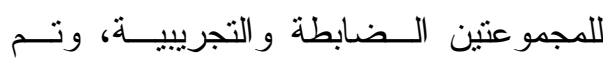
حساب المتوسطات الحــسابية و الانحر افــات ولتهن المعيارية لدرجات تلاميذ مجموعني البحــثـ

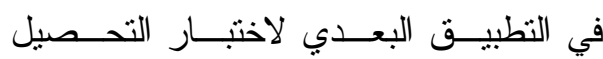
المعرفي، و الجدول التالي يوضح ذلك: جدول (المتوسطات والاتحر افات المعيارية لارجات تلاميذ مجموعتي الدراسة في التطبيق البعدي لاختبار

\begin{tabular}{|c|c|c|c|}
\hline \multicolumn{4}{|c|}{ التحصيل المعرفي ) } \\
\hline المعياري & المتوسط & علداب & لمجموعة \\
\hline 0,1 & 19 & 10 & الضابطة \\
\hline $9, r$ & $r V$ & 10 & التجريبية \\
\hline
\end{tabular}

r الإجابة عن السؤال الثاني: للإجابة عن

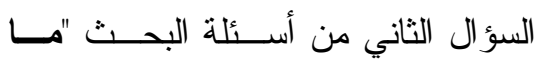

معايير تصميم بيئة تعلم تكيفية قائمسـة

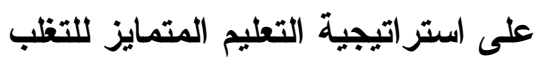
على صعوبات تعلم القواعــــ النحويـــة

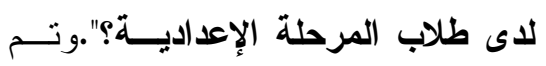

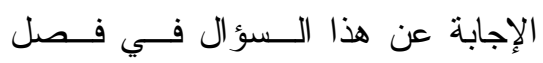
إجر اءات البحث وتحديداً في ملحق (r)، الاجدابه وذللك نظر اً لكونه سؤ ال إجر ائي. r) الإجابة عن السؤال الثالث: للإجابة عن

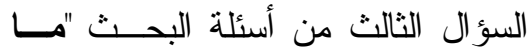
التصميم التعليم المقترح لبيئة الــتعلم

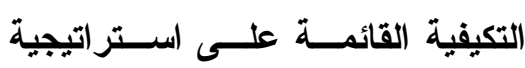
التعليم المتمايز لعلاج صعوبات تعلــم المئه القواعد النحوية لاى طلاب المرحلـــة

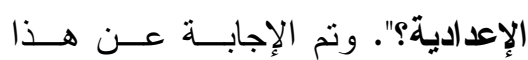

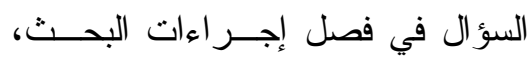
وذلك نظراً لكونه سؤ ال إجر ائي، حيث تم التصميم التعليمي للبيئة التكيفية وفقاً لنموذج (محمد الدسوقي، 10 • ب). ؛) الإجابة عن السؤال الرابع: للإجابـــة عن السؤال الخامس من أسئلة البحث "

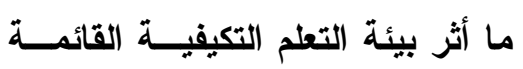
على استر اتيجية التعليم المتمايز في علاج صعوبات تعلم القواعد النحوية لاى طلاب المرحلة الإعدادية ؟". ونم 
التجريبية فــي التطبيــن البعـدي لاختبــار

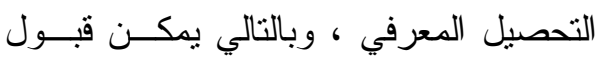
الفرض الأول و الذي نص على أنه :

"توجد فروق ذات دلاهـة إحسـصائية عنـــ

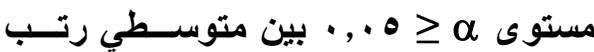
تلاميذ المجموعة التجريبية و الضابطة فــي مئي التطبيق البعدي للاختبار التحــصيلي فــي

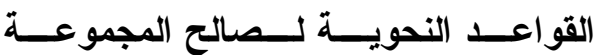
التجريبية".

ولتحديد حجم تأثثر (المتغير المستقل) بيئة تعلم تكيفية قائمة على استر اتيجية التعليم

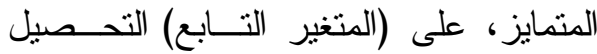

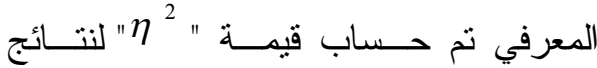

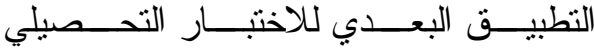
للمجمو عتين، و الجدول التالي يوضح ذلك: جدول (حجم تأثير المتغير المستقل على (التحصيل المعرفي)

\begin{tabular}{|c|c|c|c|}
\hline$\eta^{2} \stackrel{\text { التأثير" }}{2}$ & الحرية & المحسوبة & المجموعة \\
\hline , VOr & $1 \varepsilon$ & $r, .9$ & الضابطة \\
\hline . & $1 \varepsilon$ & r4,79 & التجرييية \\
\hline
\end{tabular}

يتضح من بيانات الجـدول (•(1) أن ro, r \% من التغير الذي حدث في التحــصيل المعرفي لدى تلاميذ (عينة البحث) للمجمو عة الضـابطة، يرجع إلى الطريقة التقليديــة، و أن

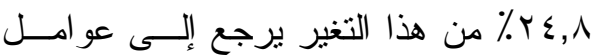

يتضح من نتائج الجدول السابق تفوق

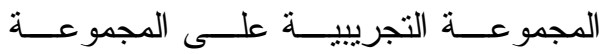
الضابطة، وأن هناك تحسناً بدرجة كبيرة في

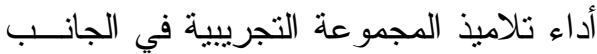
المعرفي لتعلم القو اعد النحوية، ويستخل على لنى

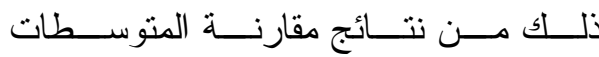

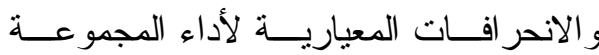
الضابطة و المجمو عة التجريبية في الإختبــار

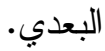
وقام الباحث باستخدام اختبــار "مــان وتني" وذلك لمعرفة دلالة الفرق بين منوسط رتب درجات طلاب المجموعــة الــضابطة ومتوسط رتب درجات طـــلاب المجموعـــة التجريبية في التطبيــق البعـدي للاختبــار التحصيلي، و الجدول التالي يوضح ذلك: جدول(دلالة الفروق بين متوسطي رتب درجات المجموعة الضابطة والتجريبية في التطبيق البعدي

\begin{tabular}{|c|c|c|c|c|c|c|}
\hline \multicolumn{7}{|c|}{ للاختبار التحصيلي) } \\
\hline ستوى & قيمة & قيمة & & ولوس & عدد & \\
\hline الدلالة & $(\mathbf{z})$ & (u) & الرتب & [الرتب & الطلاب & \\
\hline \multirow{2}{*}{$\cdot, \cdot}$, & \multirow{2}{*}{$|r, \pi|$} & \multirow{2}{*}{$\cdot, 00$} & $0 \leqslant, 0$ & $0, \varepsilon \leqslant$ & 10 & الضابطة | \\
\hline & & & 1,7 & $|7, . \leq|$ & 10 & التجريبية| \\
\hline
\end{tabular}

يتضح من نتائج الجدول السابق وجود فرق دال إحصائياً عند مستوى دلالة (0. ل, •) بين متوسطي رتب درجــات المجمــوعتين

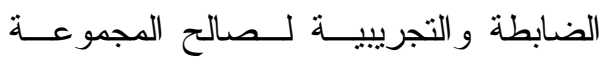


ولاختبار صحة هذا الفرض تمت المعالجــة

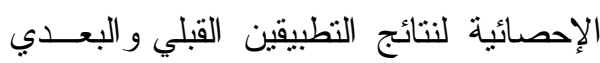
للاختبار التحصيلي للمجموعـــة التجريبيــة، وقام الباحث بحساب المتوسطات الحسـابية

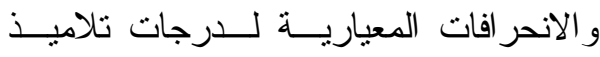

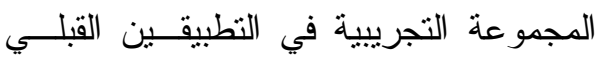
و البعدي للاختبار التحصيلي، و الجدول التالي

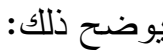

جدول (المتوسطات والانحر افات المعيارية لارجات تلاميذ المجموعة التجريبية في التطبيقين القبلي والبعدي لاختبار التحصيل

\begin{tabular}{|c|c|c|c|}
\hline \multicolumn{4}{|c|}{ المعرفي) } \\
\hline المعيار ي الإحر اف & المتوسط & الطلاب & المجموعة \\
\hline $7, \wedge$ & $10, \varepsilon$ & 10 & قبلي \\
\hline $9, r$ & $r V$ & 10 & بعدي \\
\hline
\end{tabular}

يتضح من نتائج الجدول السابق تفوق

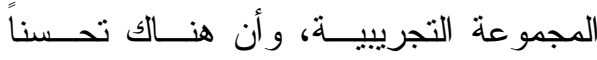

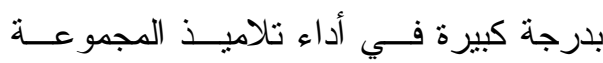

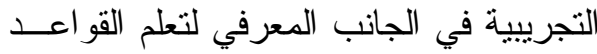

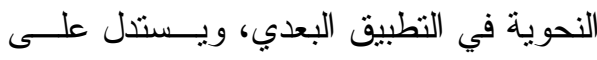

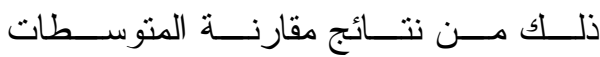

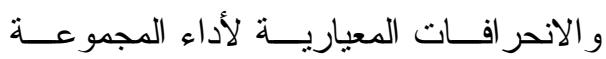
التجريبية في التطبيقين القبلي و البعدي. وتم تطبيــق اختبـــار "ويلكوكـسون"

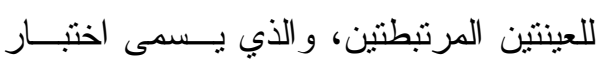

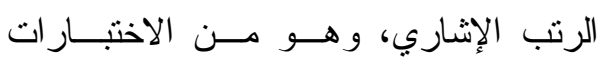

الصدفة (العوامل العشوائية) مما يؤكد فاعلية الطريقة التقليدية في تتمية التحصيل المعرفي لدى المجموعة الضابطة. ويتضح من بيانات الجـدول (• (1) أن

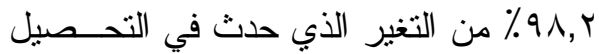
المعرفي لدى تلاميذ (عينة البحث) للمجمو عة الميرك التجرييية، يرجع إلى بيئة تعلم تكيفية قائمــة

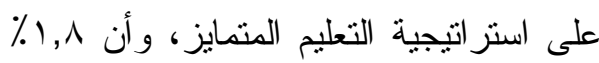
من هذا التغير يرجع إلى عو امسلـل الـصدفة (العو امل العشو ائية) مما يؤكد فاعليــة بيئـــة تعلم تكيفية قائمة على اســـر اتيجية التعلـــيم المتمايز في تتمية التحصيل المعرفـي لـــى المجمو عة التجريبية. وقد اتفقت هذه النتــائج مــع نتــائج

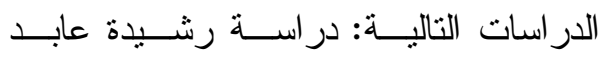

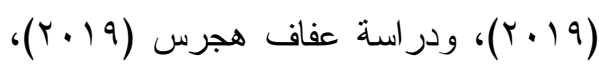

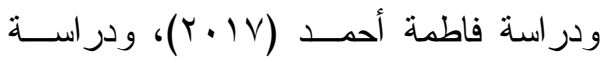

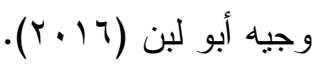
الفرض الثاني: وتم اختبار صحة الفرض الثالث من فروض البحث، و الذي نص على أنه: "يوجد فرق دال إحصائياً عند مستوى $\alpha$ ج ه .,.

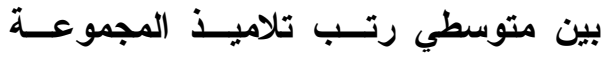
التجريبية في التطبيقين القبالــي والبعـدي

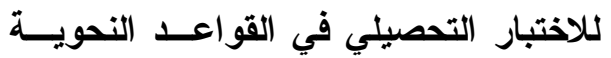

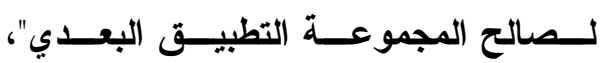


للاختبار التحصيلي في القواعــــ النحويــة لصالح المجموعة التطبيق البعدي". ولتحديد حجم تأثير (المتغير المستقل) بيئة تعلم تكيفية قائمة على استر اتيجية التعليم المتمايز، على (المتغير التـابع) التحـــيل

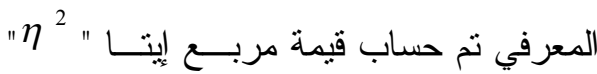
لنتائج التطبيق القبالــي و البعـدي للاختبــــار التحصيلي، و الجدول (r/) يوضح ذلك: جدول (حجم تأثير المتغير المستقل على

\begin{tabular}{|c|c|c|c|}
\hline \multicolumn{4}{|c|}{ التحصيل المعرفي) } \\
\hline التأثير" حجم ${ }^{2}$ & الدرية & المسوبة & التطبيق \\
\hline מי & $1 \leq$ & ro, 1q & القبلى \\
\hline . q४r & $1 \leqslant$ & $r 4,7 q$ & البعدي \\
\hline
\end{tabular}

يتضح من بيانات الجـدول (rآ) أن

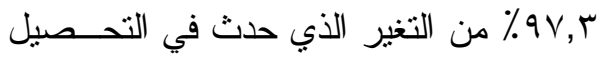
المعرفي لدى تلاميذ (عينة البحث) للمجموعة منير التجريبية، يرجع إلى بييئة تعلم تكيفية قائمــة

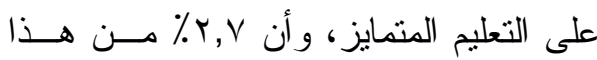

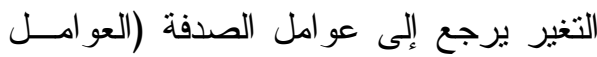
العشو ائية) مما يؤكد فاعلية بيئة تعلم تكيفيــة إلئة

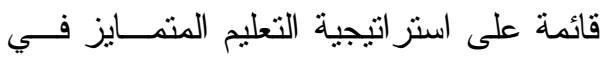
تتمية التحصيل المعرفي لدى تلاميذ (عينـــة البحث) من المجموعة التجرييية.

وللتأكد من فاعلية بيئة التعلم التكيفيــة القائمة على استر اتيجية التعليم المتمايز فـي
اللابار امترية التي تستخدم كبــديل لاختبـــار (ت) للعينتين المرتبطتين من البيانات، وذلك

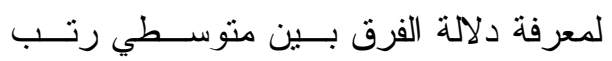
درجات المجموعة التجريبية في التطبيقـين القبلي و البعدي للاختبار التحصيلي، و الجدول النالي يوضح ذلك: جلول (دلالة الفروق بين متوسط رتب درجات المجموعة التجريبية في التطبيقين

\begin{tabular}{|c|c|c|c|c|c|}
\hline \multicolumn{6}{|c|}{ القبلي والبعدي للاختبار التحصيلي) } \\
\hline لمس & "ئي & مجد & سط & لالب & رالت \\
\hline 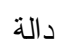 & & $\cdot, \cdot$ & , & 10 & سالبة \\
\hline & $r, V_{0}$ & $r$. & $r, \ldots$ & 10 & \\
\hline
\end{tabular}

يتضح من الجدول الــسابق أن قيمــة إحصائي "Z" دالة عند مستوى دلالة (1 +, •)؛ مما يدل علــى وجـــود فــروق ذات دلالـــة إحصائية بين منوسطي رثب درجات تلاميذ المجموعة التجريبية في التطبية لـين القبلــي و البعدي للاختبار التحصيلي لصالح التطبيــق البعدي، ومن ثم قبول الفرض الثالــث مــن فروض البحث، و الذي ينص علــى "يوجـــ

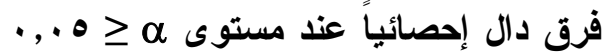

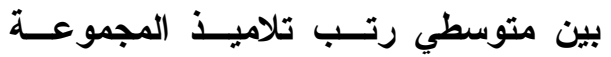
التجريبية في التطبيقين القبلــي والبعـدي 
تتمية التحصيل المعرفي للقو اعد النحوية لدى وتتضح من خلال الأتـي: ف ب = -

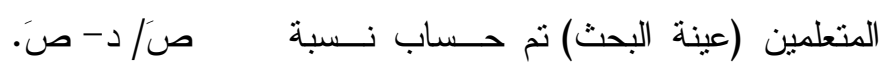

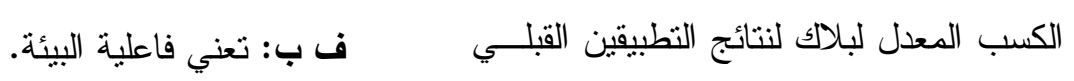
سَ: تعني متوسط درجات الاختبار البعدي على المجموعة التجريبية. صَ: تعني متوسط درجات الاختبار القبلي للمجمو عة التجرييية. دـ: تعني الدرجة القصوى على الاختبار .

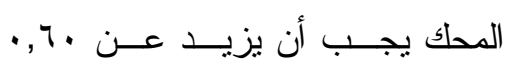

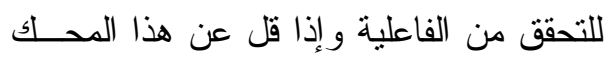

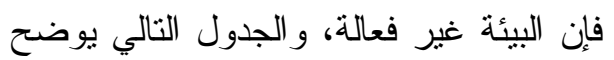
ذلك:

جدول (نسبة الفاعلية لنتائج التطبيقين

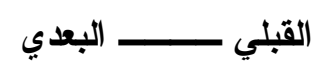

للاختبار (التحصيلي للمجموعة التجريبية)

\begin{tabular}{|c|c|c|c|}
\hline نسبة & النهاية & المتوسط & المتوسط \\
\hline الفاعلية & العظمي & البعدي & القبلي \\
\hline ف ب & د & سن & صَ \\
\hline 1,Or & $r$. & YV & $10, \varepsilon$ \\
\hline
\end{tabular}

من الجدول (10) يتــضح أن نـسبة

الفاعلية لماك جوجيان التي حققتها بيئة التعلم التكيفية القائمة علـى اســتر اتيجية التعلــيم المتمايز في تتمية التحصيل المعرفي للقواعد

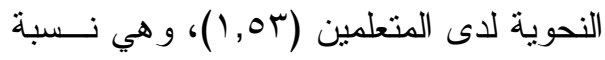
فاعلية تزيد عن (• ؟, ·)، مما يؤكد فاعليــة بيئة التعلم التكيفية القائمة على اســتراتيجية لتحلية

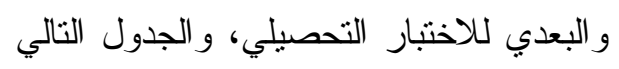
يوضح ذلك: جدول (الكسب المعدل لنتائج التطبيقين

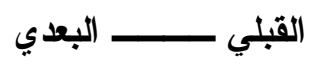

للاختبار التحصيلي للمجموعة التجريبية)

\begin{tabular}{|c|c|c|c|}
\hline الكسب & العظمي & البعدي & القبلي \\
\hline$r, \cdot \Lambda$ & r. & TV & $10, \varepsilon$ \\
\hline
\end{tabular}

بتضح أن نسبة الكسب المعدل التي

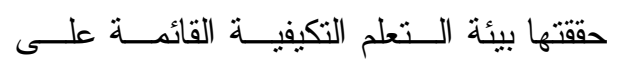

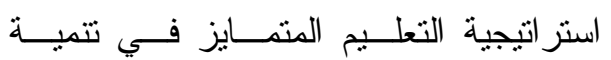

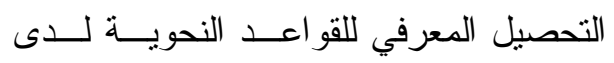

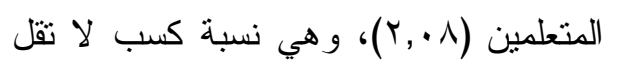

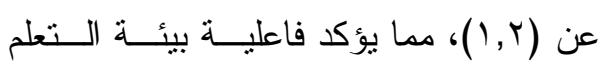
التكيفية القائمة علـى اســـنـ اتيجية التعلــيم المتمايز في تتمية التحصيل المعرفي للقو اعد النحوية لدى المتعلمين (عينة البحث). وللتأكد من فاعلية بيئة التعلم التكيفيــة القائمة على استراتيجية التعليم المتمايز فــي لتئي تتمية التحصيل المعرفي للقواعد النحوية لدى

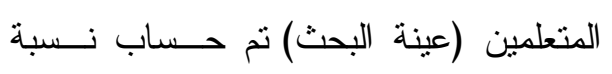

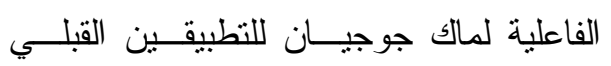
و البعدي للاختبار التحصيلي : 


$$
\begin{aligned}
& \text { r) ما تميزت به بيئــة الــتعلم التكيفــي } \\
& \text { التعليم المتمايز في تتمية التحصيل المعرفـي }
\end{aligned}
$$

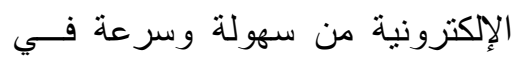

$$
\begin{aligned}
& \text { الاستخدام، و إمكانية الوصول من إليها من وسن }
\end{aligned}
$$

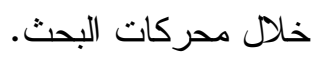

$$
\begin{aligned}
& \text { ثالثاً: توصيات البحث : } \\
& \text { في ضوء نتائج البحث يوصي الباحــث بمـــا }
\end{aligned}
$$

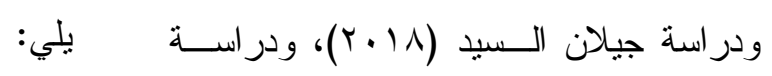

$$
\begin{aligned}
& \text { ( ) إجر اء مزيد من البحوث و الدراســات } \\
& \text { حول الدمج بين استراتيجيات الــتعلم } \\
& \text { المختلفة وبيئات التعلم التكيفية لما لها لهان لهان } \\
& \text { من فاعلية كبيرة. } \\
& \text { r التمية العديد مسـن مهــار ات الــتعلم }
\end{aligned}
$$

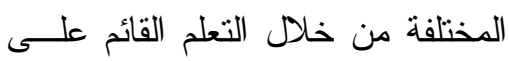

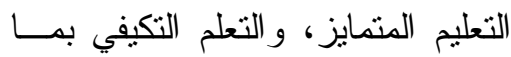

$$
\begin{aligned}
& \text { يزيد من فاعلية التعلم وتحقيق أقصى } \\
& \text { استفادة من المحتوى التعليمي المقدم. } \\
& \text { r) توجية المتعلمين إلى أســلوب الــتعلم } \\
& \text { الذي يتتاسب مع قدر اتهم وخصائص } \\
& \text { تعلمهم، وذللك لجعل التعلم المقدم أكثر } \\
& \text { فاعلية وتأثثر على مستوى التحــصيل } \\
& \text { رابعاً: مقتزحات البحث: الديهم. }
\end{aligned}
$$

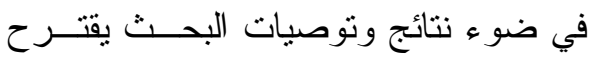

$$
\begin{aligned}
& \text { الباحث إجر اء البحوث التالية: } \\
& \text { () فاعلية استز اتيجية التعليم المتمايز ببيئــة }
\end{aligned}
$$

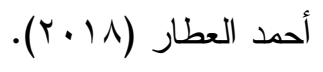

$$
\begin{aligned}
& \text { ثانياً: تفسير نتائج البحث: } \\
& \text { ويمكن إرجاع تحقق نتائج البحث إلــى مــــا }
\end{aligned}
$$

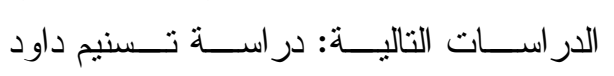

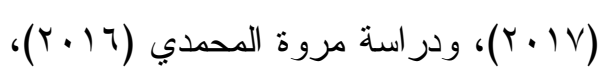

$$
\begin{aligned}
& \text { البحث). } \\
& \text { وقد اتفقت هذه النتــائج مـــع نتــائج }
\end{aligned}
$$

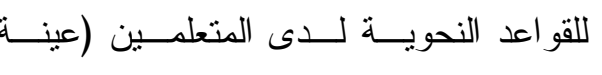

.




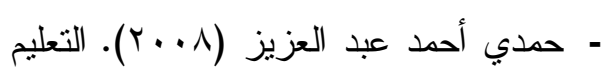

$$
\begin{aligned}
& \text { للقو اعد النحوية لدى طــلاب المرحلـــة }
\end{aligned}
$$

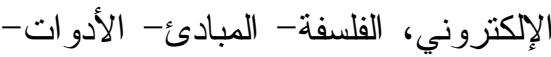

$$
\begin{aligned}
& \text { النطبيقات، عمان: دار الفكر . } \\
& \text { - حسام العباسي مصطفي (9 . . ץ). "ثورة } \\
& \text { المعلومات وتحديات العصر الحديث. } \\
& \text { - حسن الباتع محمد عبد العاطي والسيد عبد ولمال }
\end{aligned}
$$

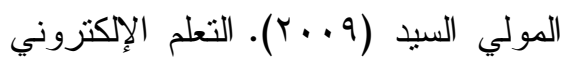

$$
\begin{aligned}
& \text { الرقمي (النظرية. التــصيم. الإنتــاج). } \\
& \text { الإسكندرية: دار الجامعة الجديدة. }
\end{aligned}
$$

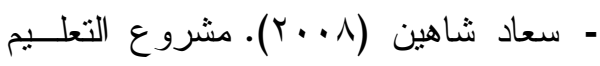

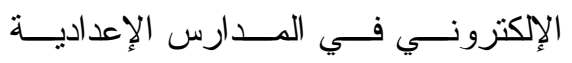

$$
\begin{aligned}
& \text { بجمهورية مصر العربية، جامعة طنطا. }
\end{aligned}
$$

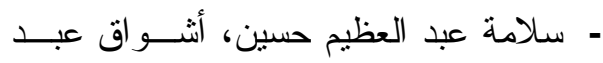

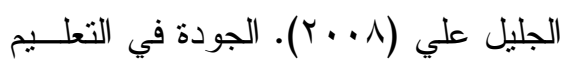

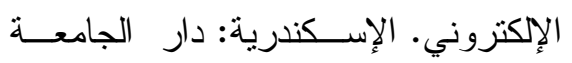

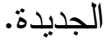

$$
\begin{aligned}
& \text { - صداح أحمد مــر اد (11 ـ ب). الأســاليب }
\end{aligned}
$$

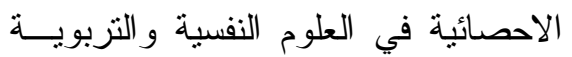

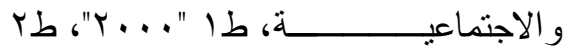

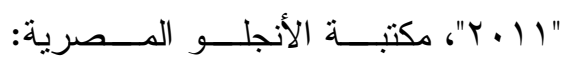

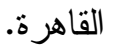

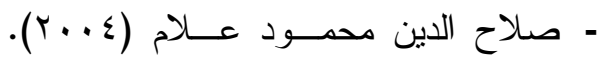

$$
\begin{aligned}
& \text { التقويم التربوي البديل؛ أسـسـه النظريـــة } \\
& \text { و المنهجية وتطبيقاته الميدانية، دار الفكـر } \\
& \text { العربي: القاهرة. }
\end{aligned}
$$

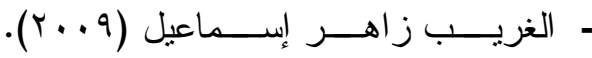

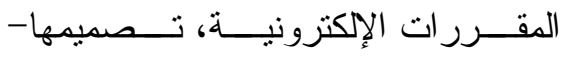

$$
\begin{aligned}
& \text { الإعدادية. } \\
& \text { r) تصميم بيئة تعلم تكيفي إلكترونية قائمسـة }
\end{aligned}
$$

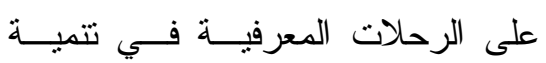

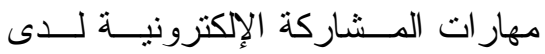

$$
\begin{aligned}
& \text { الطلاب. - بوات } \\
& \text { مراجع البحث } \\
& \text { - ذ ذوقان عبيــدات وســـيلة أبــو الـسميد }
\end{aligned}
$$

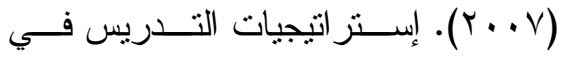

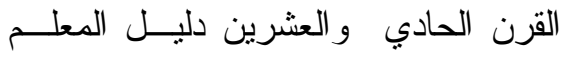

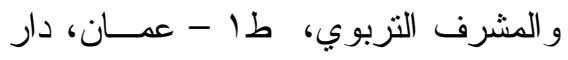

$$
\begin{aligned}
& \text { الفكر }
\end{aligned}
$$

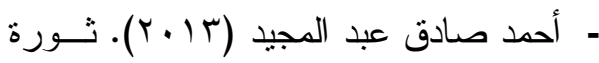

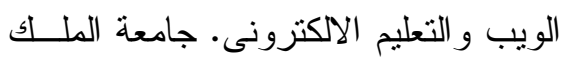

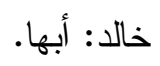

$$
\begin{aligned}
& \text { - آمال صادق، فؤاد أبو حطـب (1997 (1). } \\
& \text { علم النفس التزبوي، طه، مكتبة الأنجلــو هول }
\end{aligned}
$$

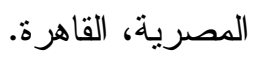

$$
\begin{aligned}
& \text { الإلكتروني: المفهوم- القضايا- التقيــيم. } \\
& \text { الرياض: الدار الصوتية للتربية. }
\end{aligned}
$$


grades 3-12 by. Free Spirit Publishing .

- Gaskill, J., \& Marshall,M., ( 2007). Comparisons Between Paper and Computer-Based Tests .Tasa Institute: Socictr for the Advancement of Excellence in Eduation.

- Fouad,k.M.Harb, H.M\&Nagdy, M.N.(2011). Semantic Web supporting Adaptive E-Learning to build and represent Learner Model. The Second International Conferece of E-Learning and Distance Education, Riyadh.

- Esichaikul, V., Lamnoi, S., \& Bechter, C. (2011). Student modelling in adaptive e-learning systems. Knowledge Management \& E-Learning: An International Journal, 3(3), 342355.

- Brusilovsky, p.(2005) Adaptive Educational Hypermedia; from Generation to Generation. Proceedings of 4 Hellenic conference on information and communication technologyies in education Athens Greec.pp19-33

- Briggs, J.C \& Stuart H .(2012, April).Online versus Paper Student Evaluations of Teachers: Analysis of Comments. International Journal of Instructional Technology \& Distant Learning, 9(2), 19-26

$$
\begin{aligned}
& \text { إنتاجها- نشرها - تطبيقهــا- تقويمهــا، } \\
& \text { القاهرة: عالم الكتب. } \\
& \text { - محمد عطية خمــيس (Y) (Y). بيئـات }
\end{aligned}
$$

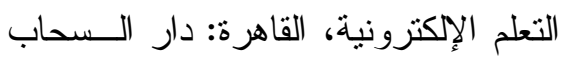

$$
\begin{aligned}
& \text { للنشر و التوزيع. }
\end{aligned}
$$

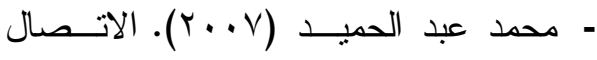

$$
\begin{aligned}
& \text { و الإعلام علي شبكة الإنترنت. القـاهرة: } \\
& \text { عالم الكتب. }
\end{aligned}
$$

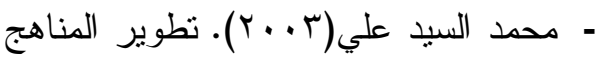

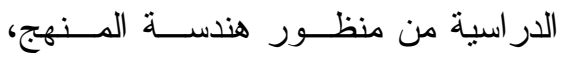

$$
\begin{aligned}
& \text { القاهرة: دار الفكر العربي. }
\end{aligned}
$$

- Jabari, N.A., \& Hariadi,M., \& Purnomo,M.H.(2011, December). Purnomo Intelligent Adaptive Presentation and eTesting System based on User Modeling and Course Sequencing in Virtual Classroom. International Journal of Instructional Technology \& Distant Learning, 8(12),59-72.

- Kim, D.H., (2006). A Comparison of Student Performance Between Paperand-Pencil and Computer-Based Testing in Four Subject Areas.(PhD). College of Education. South Carolina University.

- Heacox , Diane (2001) Differentiating Instruction in the Regular Classroom; How to reach and teach ALL learners, 


\begin{tabular}{|c|c|}
\hline Technologies & - Brusilovesky,p. \\
\hline Bloommsburg & Hypermedia \\
\hline Pennsylvania, USA. & Education and Training in; $p$. \\
\hline Affholder, L. P. (2003). & Adaptive Technologies for \\
\hline Inclusive & - Amanda,A.,Andrea,M\&.Mike,M \\
\hline Classrooms-published & . $(20$ \\
\hline $\begin{array}{l}\text { EdD. University of Kansas, } \\
\text { Kansas. }\end{array}$ & $\begin{array}{l}\text { In E-learning Concepts and } \\
\text { Techniques , Institute for }\end{array}$ \\
\hline
\end{tabular}

